\title{
Assessment of Bioactive Compounds under Simulated Gastrointestinal Digestion of Bee Pollen and Bee Bread: Bioaccessibility and Antioxidant Activity
}

\author{
Volkan Aylanc ${ }^{1}\left(\mathbb{D}\right.$, Andreia Tomás ${ }^{1}$, Paulo Russo-Almeida ${ }^{2} \mathbb{D}$, Soraia I. Falcão ${ }^{1}$ and Miguel Vilas-Boas ${ }^{1, *(\mathbb{D})}$ \\ 1 Centro de Investigação de Montanha (CIMO), Instituto Politécnico de Bragança, Campus de Santa Apolónia, \\ 5300-253 Bragança, Portugal; volkan@ipb.pt (V.A.); tomas@ipb.pt (A.T.); sfalcao@ipb.pt (S.I.F.) \\ 2 Laboratório Apícola-LabApis, Departamento de Zootecnia, Universidade de Trás-os-Montes e Alto \\ Douro (UTAD), 5300-801 Vila Real, Portugal; prusso@utad.pt \\ * Correspondence: mvboas@ipb.pt; Tel.: +351-273-303201
}

Citation: Aylanc, V.; Tomás, A.; Russo-Almeida, P.; Falcão, S.I.; Vilas-Boas, M. Assessment of Bioactive Compounds under Simulated Gastrointestinal Digestion of Bee Pollen and Bee Bread: Bioaccessibility and Antioxidant Activity. Antioxidants 2021, 10, 651. https://doi.org/10.3390/ antiox10050651

Academic Editors: Francisco J. Barba and Jose M. Lorenzo

Received: 27 March 2021

Accepted: 20 April 2021

Published: 23 April 2021

Publisher's Note: MDPI stays neutral with regard to jurisdictional claims in published maps and institutional affiliations.

Copyright: (c) 2021 by the authors. Licensee MDPI, Basel, Switzerland. This article is an open access article distributed under the terms and conditions of the Creative Commons Attribution (CC BY) license (https:/ / creativecommons.org/licenses/by/ $4.0 /)$.

\begin{abstract}
Bee pollen and bee bread have always been regarded as excellent natural resources for application in food and pharmaceutical fields due to their rich nutrient content and diversity of bioactive compounds with health-improving properties. Extensive studies on both bee products as ingredients for a healthy diet were reported, although the data concerning their metabolization on the gastrointestinal tract is quite limited. Here, we report, at each digestive stage, the bioactive profile for both bee products, their bioaccessibility levels and the antioxidant activity evaluation. The findings indicated that the average bioaccessibility level of total phenolic and total flavonoid content for bee pollen was $31 \%$ and $25 \%$, respectively, while it was $38 \%$ and $35 \%$ for bee bread. This was reflected in a decrease of their antioxidant capacity at the end of in vitro gastrointestinal digestion, both in free radicals scavenging capacity and in reducing power. Moreover, within the 35 phytochemicals identified, the most affected by gastrointestinal digestion were phenylamides, with a complete digestibility at the end of the intestinal phase. Overall, our results highlight that bioactive compounds in both raw products do not reflect the real amount absorbed in the intestine, being bee bread more accessible in bioactive content than bee pollen.
\end{abstract}

Keywords: bee pollen; bee bread; bioactive compounds; in vitro digestion; bioaccessibility; antioxidant activity

\section{Introduction}

In recent years, there has been an increasing interest in natural products for a balanced and healthy diet accrue from concerns with the synthetic food or food additives. In this context, there has been a growing interest from research to find natural functional products that have high nutritional value and positive effects on health, which includes bee products such as bee pollen and bee bread [1].

Bee pollen is formed from the combination of the pollen collected from flowers by bees, which they add nectar and their own secretions [2]. After returning to the hive, bee pollen is stored in the comb cells, mixed with organic acids, honey and digestive enzymes secreted by bees, undergoing a lactic acid fermentation process and transforming it into a new product called "bee bread" [1]. Bee bread differs from fresh bee pollen, mostly due to the changes, which occur during the fermentation and are related to the stability and digestibility of this bee product. Bee pollen and bee bread are characterized by their nutritive richness, which is based on the essential nutrients and phytochemicals of pollen, mainly carbohydrates, proteins and phenolic compounds [3,4]. The chemical composition of these bee products can vary according to the plant origin, the nutrient status of the plant, the geographical region conditions, the soil and factors such as the collection, storage and degree of processing [2]. Besides, these variabilities often affect the diversity and amount 
of the phytochemicals, such as the phenolic compounds responsible for their biological activities and consequently resulting in different therapeutic properties [1]. The studies in bee pollen and bee bread available in the literature have mostly focused on physicochemical properties [3,5], botanical origin [4,6], microbiological evaluation [7,8], phenolic compound content $[9,10]$ and antioxidant activities [5,11].

The protective role of phytochemicals that are part of our diet has become an increasingly important area of human nutrition research $[1,4,12]$. Although most of the biological effects of bioactive compounds are attributed to their high antioxidant potential [5], it is now known that these compounds are more than just antioxidants: there is increasing evidence that long-term modest intakes of bioactive compounds may show the potential to limit the risk of degenerative diseases by protecting cells from oxidative damage [12]. Nevertheless, the simple uptake of rich phytochemical diets does not ensure its effectiveness since these compounds may be affected by the human gastrointestinal tract in different ways, and consequently, this may be reflected in their biological activity.

Hence, it is crucial to determine the changes due to bioactive compounds being exposed to the gastrointestinal tract. Although studies on the digestibility of both bee products are quite limited, there are a few papers, especially on bee pollen. Yesiltas et al. [13] determined the phenolic content and antioxidant activities of bee pollen and propolis using a gastrointestinal digestion model. Benavides-Guevara et al. [14] investigated the effect of different pretreatment applications, including enzymatic treatment, on the digestibility of bee pollen. Moreover, bee bread is reported to be more digestible than bee pollen $[1,5,8]$, but to date, there has been no digestibility study of bee bread and also no comprehensive comparative study between bee pollen and bee bread in terms of the bioactive compounds following a simulated gastrointestinal digestion model. Therefore, this study reports the comparison of the bioavailability properties of bee pollen and bee bread using an in vitro simulated digestive model: digestibility and bioaccessibility level of bioactive compounds and their antioxidant capacities.

\section{Materials and Methods}

\subsection{Standards and Reagents}

Ethanol, sodium phosphate, potassium phosphate, acetonitrile, sodium hydroxide, trichloroacetic acid, hydrochloric acid, gallic acid, potassium ferricyanide, ferric chloride and calcium chloride dihydrate were purchased from Fisher Scientific (Pittsburgh, PA, USA). Folin-Ciocalteu's reagent, potassium chloride, ammonium carbonate, acetic acid glacial and sodium chloride were purchased from Panreac Applichem (Barcelona, Spain). Magnesium chloride hexahydrate and aluminum chloride were from Acros Organics (Pittsburgh, PA, USA), and sodium carbonate anhydrous was purchased from Labkem (Barcelona, Spain).

Human salivary $\alpha$-amylase (A1031-1KU), porcine pepsin (P6887), porcine pancreatin $4 \times$ USP specifications (P1750), bile bovine (B3883), 2,2-diphenyl-1-picrylhydrazyl (DPPH), quercetin, chrysin and p-coumaric acid were purchased from Sigma-Aldrich (St. Louis, $\mathrm{MO}, \mathrm{USA}$ ). Kaempferol was purchased from Extrasynthese (Genay, France) and naringenin from Acros Organics (Pittsburgh, PA, USA).

\subsection{Sample Collection and Preparation}

Three different bee pollen and bee bread samples were collected in August 2019 from Apis mellifera iberiensis hives located in different apiaries, in the northeast of Portugal. The bee pollen samples, coded as BP-A1, BP-A2 and BP-A3, were collected from the northwest of Bragança (Poulão), southeast of Bragança (Pinheiro Manso) and Vila Real, respectively, while the bee bread samples, coded as BB-A1, BB-A2 and BB-A3, were collected from the northwest of Bragança (Poulão), southeast of Bragança (Pinheiro Manso) and Miranda do Douro (Póvoa), respectively. The pollen samples were collected using pollen traps, while combs with bee bread were removed from inside of the beehives. Within the laboratory facilities, bee pollen samples were cleaned from debris of wood and dead 
bee parts, while combs were crushed manually to extract bee bread. All samples were freeze-dried and stored at $-20^{\circ} \mathrm{C}$ for further analysis.

\subsection{Palynological Analysis}

The homogenized sample, about $1 \mathrm{~g}$, were placed in separate $50 \mathrm{~mL}$ Falcon tube with distilled water, followed by vigorous stirring to disrupt pollen and allow a representative subsample. Then, $200 \mu \mathrm{L}$ were taken from the resulting mixture and centrifuged at $1000 \times g$ for $5 \mathrm{~min}$. The obtained pellet was subjected to acetolysis according to the method reported previously [15]. Pollen identification and counting were performed using an optical microscope. More than 1200 grains per preparation were counted following the criteria of Vergeron [16].

\subsection{Phenolic Compounds Extraction}

The extraction was carried out according to the method reported by Tomás et al. [4]. Briefly, bee pollen and bee bread samples were powdered using a lab type blender and $2 \mathrm{~g}$ of each sample was mixed with $40 \mathrm{~mL}$ of $\mathrm{EtOH} / \mathrm{H}_{2} \mathrm{O}(80: 20, v / v)$, then stirred at room temperature for $6 \mathrm{~h}$. The resulting mixture was filtered through a Whatman No. 4 filter paper and the residue was re-extracted under the same conditions. After, the extracts were combined and the solvent was evaporated at $40{ }^{\circ} \mathrm{C}$ in a rotavapor (Rotary Evaporator model Hei-VAP from Heidolph, Schwabach, Germany). Finally, bee pollen and bee bread extracts were freeze-dried using a lyophilizer (FreeZone 4.5 model 7750031 from Labconco, Kansas City, KS, USA) and stored at $-20^{\circ} \mathrm{C}$ until further analysis.

\subsection{Phenolic Content}

\subsubsection{Total Phenolic Content}

Total phenolic content (TPC) was determined by the Folin-Ciocalteu method [17]. In the procedure, $0.5 \mathrm{~mL}$ of ethanolic extract $(1 \mathrm{mg} / \mathrm{mL})$ was mixed with $0.25 \mathrm{~mL}$ of FolinCiocalteu reagent. After $3 \mathrm{~min}, 1 \mathrm{~mL}$ of $20 \% \mathrm{Na}_{2} \mathrm{CO}_{3}$ was added and the final volume adjusted to $5 \mathrm{~mL}$ with deionized water. The solutions were left in a water bath at $70{ }^{\circ} \mathrm{C}$ for $10 \mathrm{~min}$ and then cooled in the dark for $30 \mathrm{~min}$. The absorbance was read at $760 \mathrm{~nm}$ using a spectrophotometer (Analytikijena 200-2004 spectrophotometer from Analytik Jena, Jena, Germany). The TPC value of the bee pollen and bee bread samples were expressed as milligram of gallic acid equivalent per gram of dry weight sample (mg GAE/g).

\subsubsection{Total Flavonoid Content}

The total flavonoid content (TFC) was recorded spectrophotometrically according to Falcão et al. [17]. Briefly, $0.2 \mathrm{~mL}$ of ethanolic extract $(5 \mathrm{mg} / \mathrm{mL})$ was mixed to $0.2 \mathrm{~mL}$ of $\mathrm{AlCl}_{3}$ solution $\left(2 \% \mathrm{AlCl}_{3}\right.$, in $5 \%$ glacial acetic acid, in methanol). Then $2.8 \mathrm{~mL}$ of $5 \%$ acetic acid/methanol was added to the mixture. After $30 \mathrm{~min}$ at room temperature, the absorbance was read at $415 \mathrm{~nm}$ using a spectrophotometer (Analytikijena 200-2004 spectrophotometer from Analytik Jena, Jena, Germany). The TFC value of the bee pollen and bee bread samples was expressed as milligram of quercetin equivalent per gram of dry weight sample (mg QE/g).

\subsection{LC/DAD/ESI-MS ${ }^{n}$ Bioactive Compounds Analysis}

For the analysis, bee pollen and bee bread phenolic extracts, and the soluble digestive fractions $(20 \mathrm{mg})$ were dissolved in $\mathrm{EtOH} / \mathrm{H}_{2} \mathrm{O}(80: 20, v / v, 2 \mathrm{~mL})$. All the samples were filtered through a $0.22 \mu \mathrm{m}$ membrane filter and kept in the freezer at $-20^{\circ} \mathrm{C}$, until analysis.

For the LC analyses, a Dionex UltiMate 3000 ultrapressure liquid chromatography instrument, coupled to a diode array detector (Thermo Fisher Scientific, San Jose, CA, USA) was used. The chromatographic column was a C18 column $(250 \mathrm{~mm} \times 4 \mathrm{~mm}$ id; $5 \mathrm{~mm}$ particles diameter; end-capped), from Macherey-Nagel Nucleosil: the temperature of the column was kept at $30^{\circ} \mathrm{C}$. The flow rate and the injection volume was $1 \mathrm{~mL} / \mathrm{min}$ and $10 \mu \mathrm{L}$, respectively [9]. 
For the MS analysis, a LTQ XL linear ion trap mass spectrometer (Thermo Fisher Scientific, San Jose, CA, USA) with an ESI source operating in the negative ion mode was used. The ESI conditions were in accordance with the previously reported [9].

The phenolic compounds identification was achieved comparing the chromatographic performance, UV spectra and MS data with those of reference compounds. The structural information was confirmed by combining the UV results with the MS fragmentation data previously described in the literature, whenever the reference standards were not available. Calibrations curves for the following compounds were used in the quantification p-coumaric acid $\left(0.00925-0.4 \mathrm{mg} / \mathrm{mL} ; \mathrm{y}=1.9 \times 10^{7} \mathrm{x}-12,927 ; \mathrm{R}^{2}=0.996\right)$, quercetin $\left(0.037-1.6 \mathrm{mg} / \mathrm{mL} ; \mathrm{y}=4.0 \times 10^{6} \mathrm{x}-10,216 ; \mathrm{R}^{2}=0.997\right)$, kaempferol $(0.037-1.6 \mathrm{mg} / \mathrm{mL}$; $\left.y=4.3 \times 10^{6} x-13,567 ; R^{2}=0.998\right)$, chrysin $\left(0.0185-0.8 \mathrm{mg} / \mathrm{mL} ; \mathrm{y}=1.2 \times 10^{7} \mathrm{x}-51,265\right.$; $\left.\mathrm{R}^{2}=0.999\right)$ and naringenin $\left(0.0185-0.8 \mathrm{mg} / \mathrm{mL} ; \mathrm{y}=8.0 \times 10^{6} \mathrm{x}-10,998 ; \mathrm{R}^{2}=0.998\right)$. If the standard was not available, the quantification was performed using the calibration curve of the standard structurally close, with the final result being expressed in equivalent terms, as $\mathrm{mg} / \mathrm{g}$ of sample.

\subsection{Antioxidant Activity \\ 2.7.1. DPPH Radical Scavenging Assay}

DPPH free radical scavenging activity of samples was performed according to Tomás et al. [4] with some modifications. Of the phenolic extracts $0.15 \mathrm{~mL}$, with concentrations ranging from 0.03 to $0.43 \mathrm{mg} / \mathrm{mL}$ were mixed with $0.15 \mathrm{~mL}$ of DPPH $(50 \mathrm{mg} / \mathrm{L})$ and the absorbance was read at $515 \mathrm{~nm}$ using an ELX800 Microplate Reader (Bio-Tek Instruments, Inc., Winooski, VT, USA). The percentage of radical inhibition was calculated using the following equation:

$$
\% \text { Inhibition }=\left[\left(\mathrm{A}_{\mathrm{DPPH}}-\mathrm{A}_{\text {Sample }}\right) / \mathrm{A}_{\mathrm{DPPH}}\right] \times 100
$$

The amount of antioxidant necessary to decrease the initial DPPH concentration by $50 \%$ $\left(\mathrm{EC}_{50}\right)$ was achieved plotting the inhibition percentage against the extract concentration.

\subsubsection{Reducing Power Assay}

The assay was performed according to Falcão et al. [17]. Of ethanolic extract $(1 \mathrm{mg} / \mathrm{mL})$ $0.25 \mathrm{~mL}$ of the sample was mixed with $1.25 \mathrm{~mL}$ of phosphate buffer $(0.2 \mathrm{M}, \mathrm{pH} 6.6)$ and $1.25 \mathrm{~mL}$ of $1 \%$ potassium ferricyanide, respectively. The mixture was left in a water bath at $50{ }^{\circ} \mathrm{C}$ for $20 \mathrm{~min}$. Then, $1.25 \mathrm{~mL}$ of $10 \%$ trichloroacetic acid was added to the mixture and centrifuged at $3000 \times g$ (Centurion K2R series, Chichester, UK) for $10 \mathrm{~min}$. Of the upper layer $1.25 \mathrm{~mL}$ was mixed with $1.25 \mathrm{~mL}$ of deionized water and $0.25 \mathrm{~mL}$ of $0.1 \%$ $\mathrm{FeCl}_{3}$, and the absorbance was read at $700 \mathrm{~nm}$. Gallic acid was used as standard and the results were expressed as milligram of gallic acid equivalent per gram of dry weight sample (mg GAE/g).

\subsection{In Vitro Gastrointestinal Digestion}

The static in vitro digestion model was performed according to the method developed by the COST INFOGEST international network [18]. This method consists of three sequential phases: oral, gastric and intestinal digestion, Figure 1 and Table S1 (Supplementary Material). Briefly, $5 \mathrm{~g}$ of bee pollen or bee bread samples were mixed with $3.5 \mathrm{~mL}$ simulated saliva fluid stock solution. This step is followed by the addition of $0.5 \mathrm{~mL} \alpha$-amylase solution of $1500 \mathrm{U} / \mathrm{mL}$. Then, $\mathrm{pH}$ was adjusted to 7 with $1 \mathrm{~mol} / \mathrm{L} \mathrm{NaOH}$ and incubated in a water bath, on the dark, at $37^{\circ} \mathrm{C}$ for 2 min with constant shaking. In the gastric phase, the oral bolus was mixed with $7.5 \mathrm{~mL}$ of simulated gastric fluid stock solution followed by $1.6 \mathrm{~mL}$ pepsin solution of $25,000 \mathrm{U} / \mathrm{mL}$. Then, $\mathrm{pH}$ was adjusted to 3 with $1 \mathrm{~mol} / \mathrm{L}$ $\mathrm{HCl}$, followed by an incubation during $2 \mathrm{~h}$ under the same conditions as in the oral phase. In the final phase, gastric chyme was mixed with $11 \mathrm{~mL}$ of simulated intestinal fluid stock solution, $5 \mathrm{~mL}$ of pancreatin solution of $800 \mathrm{U} / \mathrm{mL}, 2.5 \mathrm{~mL}$ of bile (160 mM in fresh bile) and $\mathrm{NaOH}$ (to adjust the $\mathrm{pH} 7$ ). $\mathrm{NaOH}-\mathrm{HCl}$ (both $1 \mathrm{~mol} / \mathrm{L}$ ) was used to set the $\mathrm{pH}$ back 
to 7 and incubated under the same conditions as the gastric phase. Finally, the obtained samples from the three digestion phases were centrifuged for $15 \mathrm{~min}$ at $10,000 \times \mathrm{g}$ at $4{ }^{\circ} \mathrm{C}$, the soluble and pellet fractions were stored at $-32{ }^{\circ} \mathrm{C}$ until further analysis. Each bee pollen and bee bread sample was digested in triplicate and the replicates mixed.

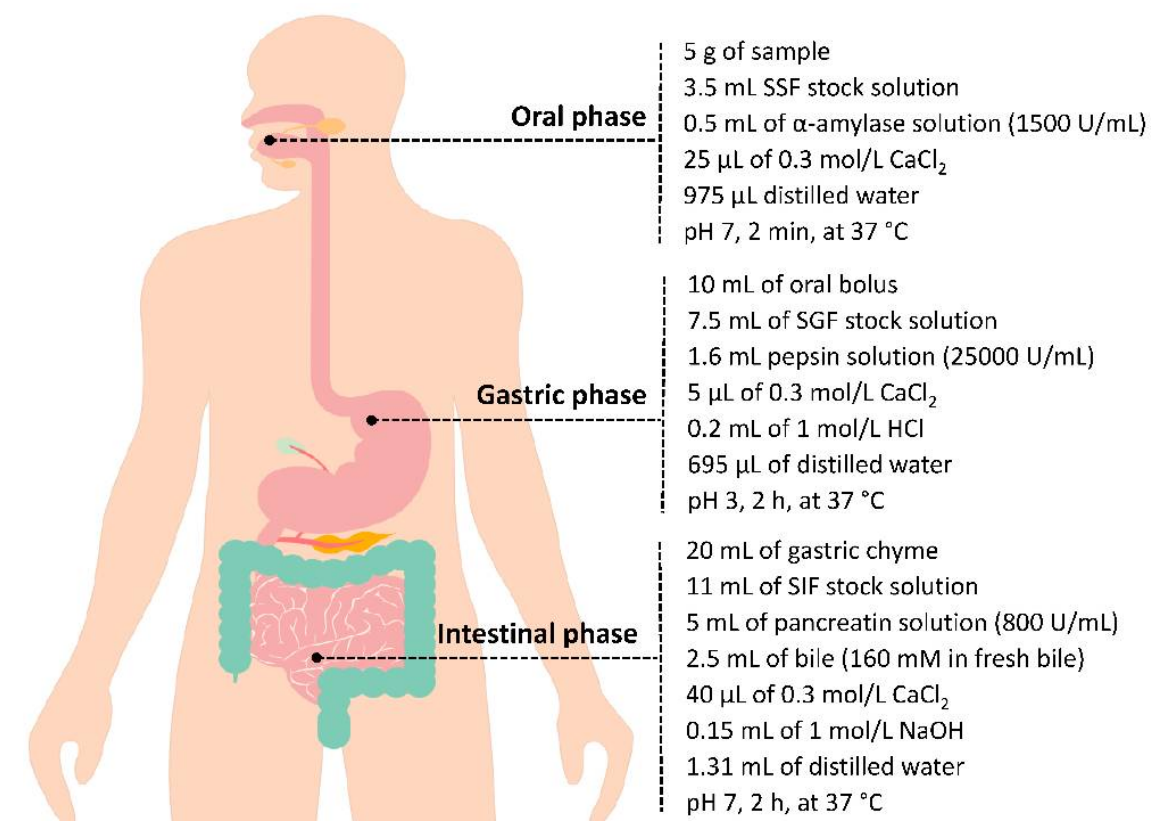

Figure 1. Overview of a simulated in vitro digestion method. Enzyme activities are in units per $\mathrm{mL}$ of the final digestion mixture at each corresponding digestion phase.

\subsection{Bioaccessibility}

Bioaccessibility (\%) was described as the amount of phenolic compounds released in the in vitro digestion process compared to the amount of phenolic compounds in the tested sample, and calculated according to the following equation [19]:

Bioaccessibility $(\%)=\left(\frac{\text { content of phenolic compounds released in the simulated digestion }}{\text { content of phenolic compounds in the tested sample }}\right) \times 100$

\subsection{Data Analysis}

All analyses were performed in triplicate and the results were denoted as mean \pm standard deviation (SD). The obtained data was analyzed using GraphPad Prism version 8 (San Diego, CA, USA). A one-way analysis of variance was performed, followed by Tukey's test for mean separation at $p<0.05$. Additionally, Pearson's correlation coefficients were calculated to ascertain the relationship between the tested parameters.

\section{Results}

\subsection{Botanical Origin of Bee Pollen and Bee Bread}

Forty pollen types were identified, at the species, genus or family level, in the bee pollen and bee bread samples. To simplify data analysis, only those with relative frequency percentages, higher than $0.1 \%$, are presented in Table 1 . A total of 17 pollen types were found at percentages greater than $3 \%$, resulting in a classification of all samples as heterofloral, since no major taxa were present at a relative frequency greater than $80 \%$ [2]. 
Table 1. Relative frequency (\%) of pollen types in bee pollen and bee bread samples.

\begin{tabular}{|c|c|c|c|c|c|c|c|}
\hline \multirow[b]{2}{*}{ Family } & \multirow[b]{2}{*}{ Pollen Types } & \multicolumn{6}{|c|}{ Relative Frequency (\%) of Pollen Types } \\
\hline & & BP-A1 ${ }^{\text {a }}$ & BP-A2 ${ }^{b}$ & BP-A3 & $\mathrm{BB}-\mathrm{A} 1^{\mathrm{a}}$ & BB-A2 ${ }^{b}$ & BB-A3 \\
\hline Amaranthaceae & Chenopodium sp. & - & 1.60 & - & - & - & 1.36 \\
\hline \multirow{2}{*}{ Apiaceae } & Eryngium & 1.02 & - & - & - & - & 0.14 \\
\hline & Thapsia vilosa & 0.11 & 6.75 & - & - & - & - \\
\hline \multirow[t]{2}{*}{ Asteraceae } & Centaurea sp. & 6.21 & 1.60 & - & 1.90 & - & - \\
\hline & Crepis capillaris & 11.17 & 59.84 & - & 0.76 & 0.80 & 1.64 \\
\hline \multirow[t]{2}{*}{ Boraginaceae } & Echium sp. & 8.80 & 0.57 & 0.72 & 4.19 & 1.50 & - \\
\hline & Pentaglotis sempervirens & - & - & - & 1.02 & - & - \\
\hline Brassicaceae & Raphanus raphanistrum & - & - & 3.79 & 0.38 & 0.10 & 1.91 \\
\hline Campanulaceae & Jasione montana & - & - & - & 0.13 & 3.40 & 21.96 \\
\hline Crassulaceae & Sedum sp. & - & - & 0.21 & 0.51 & 3.30 & 0.82 \\
\hline Ericaceae & Erica sp. & - & - & 9.03 & - & - & - \\
\hline \multirow[t]{3}{*}{ Fabaceae } & Lotus sp. & 0.11 & - & - & 1.14 & - & - \\
\hline & Cytisus striatus & - & 0.11 & 47.69 & 6.22 & 6.50 & 19.65 \\
\hline & Trifolium sp. & 5.98 & 0.23 & 1.74 & 12.18 & 6.50 & - \\
\hline \multirow[t]{2}{*}{ Fagaceae } & Castanea sativa & - & - & - & 25.38 & 47.50 & 25.51 \\
\hline & Quercus sp. & - & 0.34 & - & - & - & 6.96 \\
\hline Lamiaceae & Lavandula sp. & - & - & - & 0.38 & 1.10 & 3.27 \\
\hline Myrtaceae & Eucalyptus sp. & - & - & 24.10 & - & - & - \\
\hline Papaveraceae & - & 0.34 & 0.23 & 3.49 & 0.25 & 2.20 & 0.55 \\
\hline Plantaginaceae & Plantago sp. & 47.18 & 20.14 & 0.10 & 2.79 & 1.20 & 1.91 \\
\hline Poaceae & Zea mays & 1.81 & - & - & - & - & - \\
\hline \multirow[t]{2}{*}{ Resedaceae } & Sesamoides sp. or Reseda sp. & - & - & 1.85 & 0.13 & 0.20 & - \\
\hline & Rhamnus alaternus & - & - & 0.10 & 1.02 & - & - \\
\hline \multirow[t]{2}{*}{ Rosaceae } & - & - & - & 1.33 & - & - & 0.68 \\
\hline & Rubus sp. & 0.56 & - & 2.67 & 37.31 & 22.30 & 10.23 \\
\hline Salicaceae & Salix sp. & - & - & 1.33 & 0.51 & 0.80 & - \\
\hline Solanaceae & - & - & 2.06 & - & - & - & - \\
\hline
\end{tabular}

a,b The same letters represent samples collected in the same apiary. Dominant pollen ( $>45 \%)$; accessory pollen (15-45\%) and isolated pollen (3-15\%).

In the BP-A1 sample, Plantago sp. (47\%) from Plantaginaceae family was the dominant pollen type, while Crepis capillaris $(60 \%)$ from the Asteraceae family was the dominant pollen type in BP-A2. For the BP-A3 sample, Cytisus striatus (48\%) from the Fabaceae family was the dominant taxa.

The presence of dominant taxon was not so evident for BB-A1 and BB-A3 samples. Instead, several different families had distribution at the accessory or isolated pollen level, with higher prevalence on Cytisus striatus (Fabaceae), Castanea sativa (Fagaceae), Jasione montana (Campanulaceae) and Rubus sp. (Rosaceae). Castanea sativa (48\%) was the only dominant pollen type in the BB-A2 sample, followed by Rubus sp. with a relative frequency value of $22 \%$. Asteraceae and Fabaceae families were described in previous studies as dominant pollens in bee pollen samples $(n=22)$ obtained from Douro International Natural Park in Portugal [3], which is in accordance to the results presently found. Besides, it is known that Castanea and Rubus pollen types are dominant in bee pollen and bee bread coming from the northern part of Portugal [4]. Even though the palynological results in the current study are in accordance with the works mentioned above, the pollen types in both bee products may vary depending on the collection season and apiary location [1].

\subsection{Total Phenolic and Flavonoid Content, and Bioaccessibility Level}

The polarities, molecular weights, differences in chemical structures and abundances of approximately eight thousand phytochemicals that exist in plants can affect in different ways the digestive process, and therefore their bioavailability may differ in the body [19]. Along with this, the total quantity of phenolic compounds in food matrices does not reflect the amount absorbed by humans. The in vitro digestion method is a simple, fast, cost- 
effective with no ethical concerns, simulation process that may provide important data on the stability of the bioactive compounds throughout the digestion process. Additionally, the obtained in vitro digestion model results show a good correlation with the data obtained from in vivo studies [20].

In the present study, the TPC and TFC of undigested (raw) and digested bee pollen and bee bread samples are illustrated in Figure 2. The TPC for raw bee pollen samples ranged from $2.4 \pm 0.1$ (BP-A2) to $4.3 \pm 0.1 \mathrm{mg} \mathrm{GAE} / \mathrm{g}$ (BP-A3), while raw bee bread samples ranged from $3.2 \pm 0.2$ (BB-A3) to $3.8 \pm 0.1 \mathrm{mg}$ GAE/g (BB-A2). The TFC in bee pollen and bee bread ranged from $0.6 \pm 0.1$ to $2.7 \pm 0.1 \mathrm{mg} Q E / \mathrm{g}$, in the following order: BP-A3 > BB-A3 > BP-A1 > BB-A2 > BB-A1 > BP-A2. The variation observed in the results was correlated to the different botanical origin of the samples or the fermentation product in the case of the bee bread samples [1]. Additionally, the TPC for the bee bread samples were more homogeneous compared to bee pollen, although the TFC had highly variable values, with statistical difference between each sample (Figure 2A,C). These findings are consistent with previous studies indicating that bee pollen and bee bread are an important source of phenolic compounds with antioxidant activity [3,5,12].
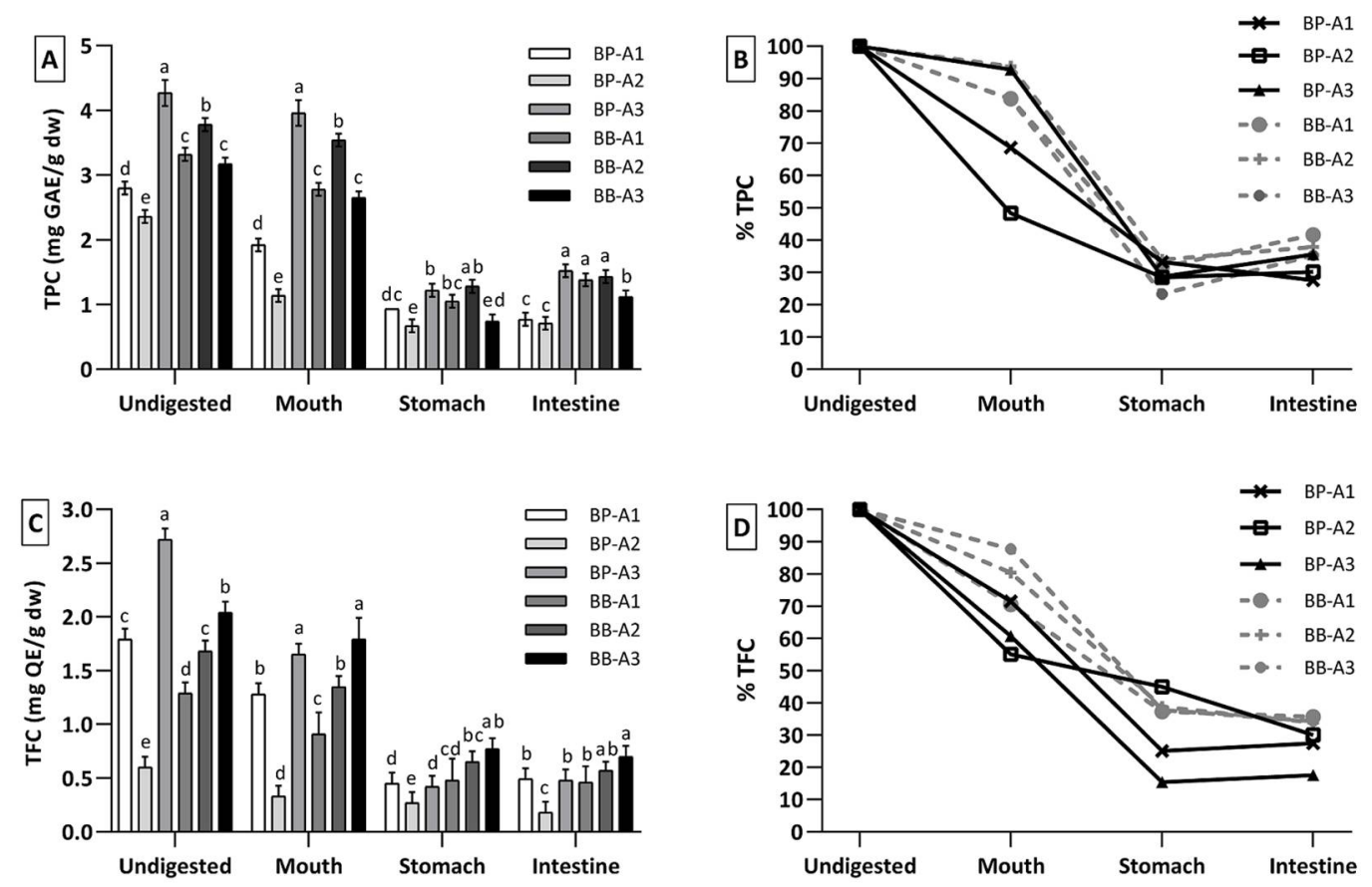

Figure 2. (A) The total phenolic content (TPC), (B) percentage change in TPC in each digestion phase, (C) the total flavonoid content (TFC) and (D) percentage change in TFC after each digestion phase. Within each group (undigested, mouth, stomach and intestine), different letters (a-e) mean significantly different $(p<0.05)$.

After undergoing the oral phase, a slight decrease was observed in the TPC of the digested pollen samples, with values of $1.9 \pm 0.1,1.1 \pm 0.1$ and $3.9 \pm 0.2$ for BP-A1, BP-A2 and BP-A3 samples, respectively, Figure 2A,B. The gastric phase was clearly more shocking, with a decrease in TPC by $52 \%$ (BP-A1), 36\% (BP-A2) and 69\% (BP-A3). In the last phase of digestion, the intestinal, the TPC in BP-A1 maintained the decreasing profile and reached a minimum of $0.8 \pm 0.1 \mathrm{mg} \mathrm{GAE} / \mathrm{g}$, while BP-A2 and BP-A3, revealed a slight increase, reaching $0.7 \pm 0.1$ and $1.5 \pm 0.1 \mathrm{mg}$ GAE $/ \mathrm{g}$, respectively. The TPC of bee bread samples showed a similar trend to bee pollen after oral and gastric phases, Figure 2B. However, a bigger increase was observed in TPC for all bee bread samples after the intestinal phase, and BB-A1, BB-A2 and BB-A3 reached $1.4 \pm 0.0,1.4 \pm 0.1$ and $1.1 \pm 0.1 \mathrm{mg}$ GAE $/ \mathrm{g}$, respectively.

According to the values reported in Figure 2C, the TFC showed a decreasing trend in the pollen samples after each digestive phase, except for BP-A1 and BP-A3 in the intestinal phase (Figure 2D). Additionally, for each pollen sample, there was no significant difference 
in TFC content between gastric and intestinal phases. On average, the TFC decrease in bee pollen samples was $77 \%$, reaching $0.5 \pm 0.1$ (BP-A1), $0.2 \pm 0.0$ (BP-A2) and $0.5 \pm 0.1 \mathrm{mg}$ $\mathrm{QE} / \mathrm{g}(\mathrm{BP}-\mathrm{A} 3)$ at the end of digestion. A continuous decrease was also observed in the TFC for the bee bread samples. After the intestinal phase, the TFC in BB-A1, BB-A2 and BB-A3 reached $0.5 \pm 0.0 \mathrm{mg} \mathrm{QE} / \mathrm{g}, 0.6 \pm 0.0 \mathrm{mg} \mathrm{QE} / \mathrm{g}$ and $0.7 \pm 0.1 \mathrm{mg} \mathrm{QE} / \mathrm{g}$, respectively.

In general, an overall decrease in the TPC of bee pollen and bee bread samples was observed at the end of the in vitro gastrointestinal digestion. Previous studies indicated that food matrices generally have a gradual decrease in their TPC as they pass through the digestive system $[19,21]$, however, there are also studies reporting a slight increase in TPC at the end of digestion, despite a decrease in the oral and gastric phase for different foods [22,23], which was also observed in the current study, where the TPC of the samples was slightly increased in the intestinal phase compared to the gastric phase, Figure 2B. This may be related to the multilayered wall structure of the pollen grains, which is resistant to digestive enzymes and $\mathrm{pH}$ changes. Additionally, the porous structure of the pollen grains may have contributed to the continuous release of phenolic compounds. Another important point is the high acidity of the stomach environment, which will have a strong effect on the released phenolic compounds [21]. Besides, the higher phenolic content released from bee bread samples comparing to the bee pollen can be explained by the partial digestion of the multilayered structure of pollen grains by bacterial enzymes throughout the fermentation process of bee bread [8]. The findings in this study are in agreement with studies reported for TFC of different food matrices [13,21].

The TFC was generally found to be in a decreasing tendency, except for BP-A1 and BB-A3 samples in the intestinal phase (Figure 2D). This decrease may be attributed to the breakdown of released and more accessible flavonoids by the action of digestive enzymes or different $\mathrm{pH}$ environments [21]. In the study conducted by Pinto et al. [24], it was reported that there was a decrease in the TFC of elderberries at the end of the digestion. Similar results have been obtained by other studies on edible mushrooms and carob flour as well $[25,26]$.

Based on the experimental results it was possible to calculate the bioaccessibility index for bee pollen and bee bread samples at the end of the digestion, as presented in Figure 3. The average TPC and TFC bioaccessibility levels for bee pollen samples were $31 \%$ and $25 \%$, respectively, while it was $38 \%$ and $35 \%$ for bee bread samples. These differences in TPC and TFC of the samples resulted in different bioavailability scores of the total quantity of compounds to be absorbed at the end of digestion. According to the findings, it can be said that bee bread is a more digestible product and so, more accessible than bee pollen in terms of bioactive compounds.
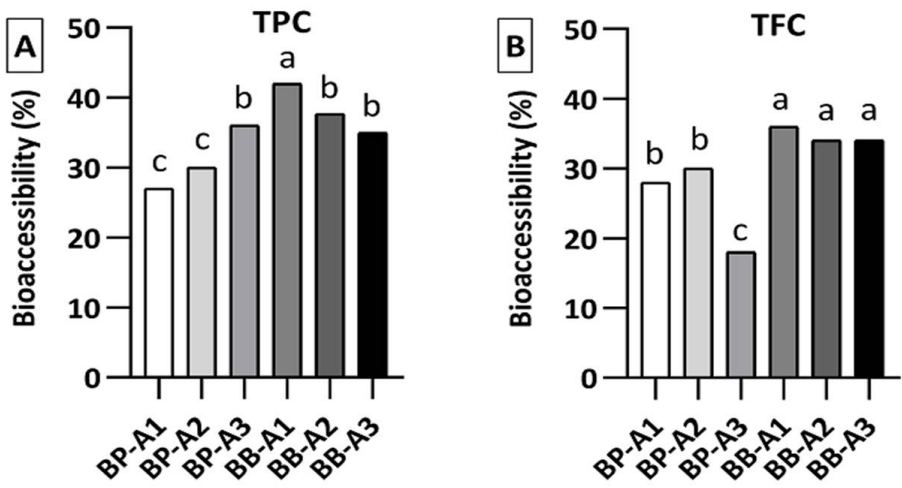

Figure 3. Bioaccessibility degree for (A) total phenolic content (TPC) and (B) the total flavonoid content (TFC). Within each graph (TPC or TFC), different letters (a-c) mean significantly different $(p<0.05)$.

\subsection{Phytochemical Profile and Bioaccessibility Level}

The individual phenolic compounds of both bee pollen and bee bread samples were investigated by LC/DAD/ESI-MS ${ }^{n}$, at the different digestion stages (Figure 4). 

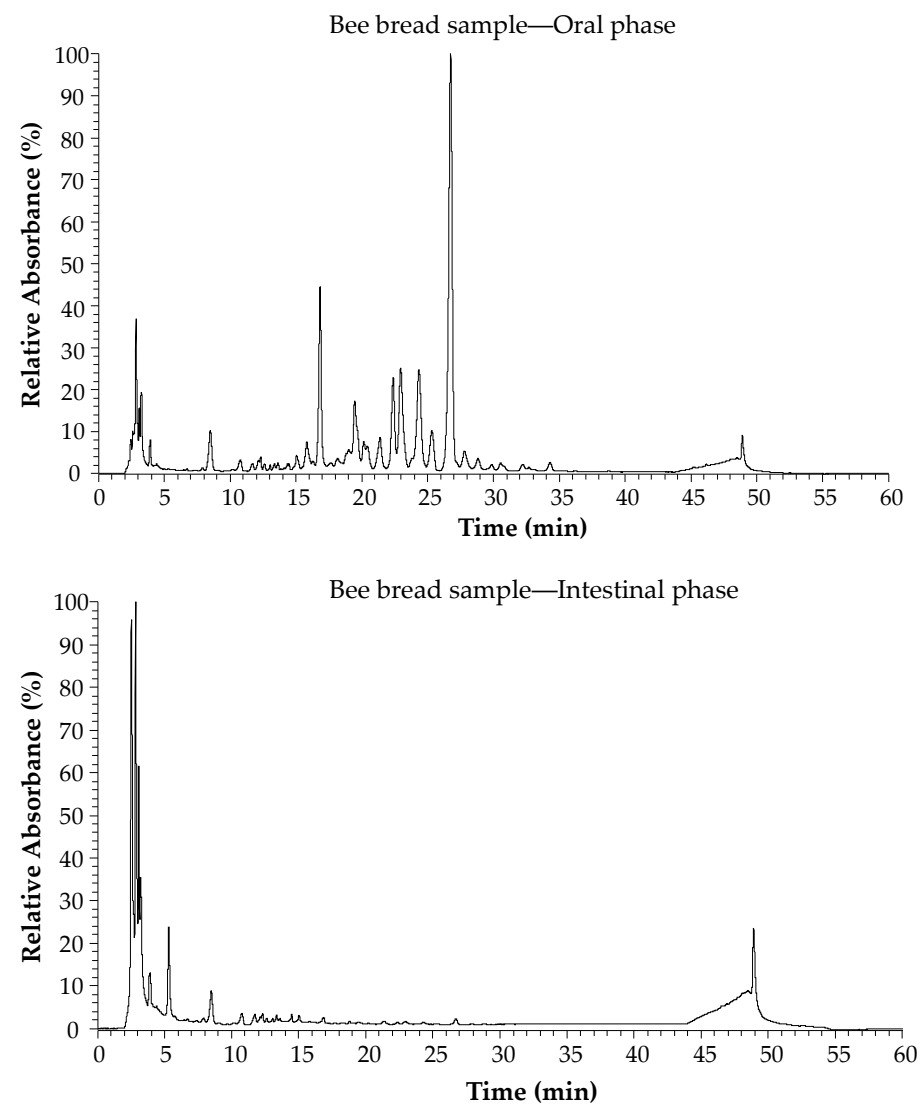

Figure 4. Chromatographic profile of bee bread sample obtained at $280 \mathrm{~nm}$ by LC/DAD/ESI-MS ${ }^{\mathrm{n}}$.

The chromatogram allowed the identification and quantification of 35 bioactive phytochemicals, which included 21 phenolic compounds (Table 2), mostly flavonols, and 14 phenylamides (conjugates of polyamines and hydroxycinnamic acids). The quantitative contribution of phenylamides was significantly higher than the other phenolic compounds.

Table 2. Phenolic and phenylamide profile of raw bee pollen and bee bread samples.

\begin{tabular}{|c|c|c|c|c|c|c|c|c|c|c|}
\hline \multirow{2}{*}{$\begin{array}{c}t_{R} \\
(\min )\end{array}$} & \multirow{2}{*}{$\begin{array}{l}\lambda_{\max } \\
(\mathrm{nm})\end{array}$} & \multirow{2}{*}{$\begin{array}{l}{[\mathrm{M}-\mathrm{H}]^{-}} \\
m / z\end{array}$} & \multirow{2}{*}{ MS $^{n}$ (\% Base Peak) } & \multirow{2}{*}{ Proposed Compound } & \multicolumn{6}{|c|}{ mg/g Raw Sample } \\
\hline & & & & & BP-A1 & BP-A2 & BP-A3 & BB-A1 & BB-A2 & BB-A3 \\
\hline 6.58 & 255,349 & 771 & $\begin{array}{c}\mathrm{MS}^{2}: 609(100) ; \mathrm{MS}^{3}: \\
301(100)\end{array}$ & $\begin{array}{l}\text { Quercetin-O-hexosyl-O- } \\
\text { rutinoside } \\
\mathrm{a}, \mathrm{c}\end{array}$ & $\begin{array}{c}0.08 \pm \\
0.0\end{array}$ & ND & ND & ND & ND & ND \\
\hline 7.48 & 257,353 & 625 & $\begin{array}{l}\mathrm{MS}^{2}: 301 \text { (100), } 300 \\
(99), 445(85), 271(18)\end{array}$ & Quercetin-diglucoside ${ }^{\mathrm{a}, \mathrm{e}, \mathrm{h}}$ & ND & ND & ND & ND & ND & $\mathrm{ND}$ \\
\hline 8.43 & $\begin{array}{l}272, \\
326 s h \\
353 \text { sh }\end{array}$ & 639 & $\begin{array}{c}\mathrm{MS}^{2}: 271(10), 300(34) \\
315(91), 459(100), 477 \\
(11), 624(20)\end{array}$ & $\begin{array}{c}\text { Methyl } \\
\text { herbacetin-O-dihexoside }^{\text {a,c,d }}\end{array}$ & $\begin{array}{c}0.04 \pm \\
0.0\end{array}$ & ND & $\begin{array}{c}0.31 \pm \\
0.0\end{array}$ & $\begin{array}{c}0.43 \pm \\
0.0\end{array}$ & $\begin{array}{c}0.33 \pm \\
0.0\end{array}$ & $\begin{array}{c}0.14 \pm \\
0.0\end{array}$ \\
\hline 9.94 & 265,348 & 609 & $\mathrm{MS}^{2}: 285(100), 429$ (49) & Kaempferol-O-dihexoside ${ }^{\mathrm{a}, \mathrm{d}}$ & $\begin{array}{c}0.08 \pm \\
0.0\end{array}$ & ND & ND & ND & ND & ND \\
\hline 10.69 & $\begin{array}{l}272 \\
326 \mathrm{sh} \\
353 \mathrm{sh}\end{array}$ & 623 & $\begin{array}{c}\mathrm{MS}^{2}: 299(61), 300(38) \\
314(100), 315(69), 459 \\
(86), 477(19)\end{array}$ & $\begin{array}{c}\text { Methyl } \\
\text { herbacetin-O-rutinoside }^{\mathrm{a}, \mathrm{c}}\end{array}$ & ND & ND & ND & $\begin{array}{c}0.09 \pm \\
0.0\end{array}$ & $\begin{array}{c}0.08 \pm \\
0.0\end{array}$ & $\begin{array}{c}0.02 \pm \\
0.0\end{array}$ \\
\hline 11.69 & 255,353 & 609 & $\begin{array}{c}\mathrm{MS}^{2}: 315 \text { (100), } 314 \\
(47), 459(51), 300(20)\end{array}$ & $\begin{array}{c}\text { Isorhamnetin-O-pentosyl- } \\
\text { hexoside } \\
\mathrm{a}, \mathrm{e}\end{array}$ & $\begin{array}{c}0.22 \pm \\
0.0\end{array}$ & $\begin{array}{c}0.07 \pm \\
0.0\end{array}$ & ND & $\begin{array}{c}0.06 \pm \\
0.0\end{array}$ & $\begin{array}{c}0.05 \pm \\
0.0\end{array}$ & $\begin{array}{c}0.06 \pm \\
0.0\end{array}$ \\
\hline 12.09 & 265,348 & 593 & $\begin{array}{l}\mathrm{MS}^{2}: 284(100), 285 \\
(73), 429(93)\end{array}$ & $\begin{array}{l}\text { Kaempferol-3-O-rutinoside } \\
\text { a,b,f }\end{array}$ & $\begin{array}{c}0.02 \pm \\
0.0\end{array}$ & $\begin{array}{c}0.00 \pm \\
0.0\end{array}$ & $\begin{array}{c}0.03 \pm \\
0.0\end{array}$ & $\begin{array}{c}0.01 \pm \\
0.0\end{array}$ & $\begin{array}{c}0.02 \pm \\
0.0\end{array}$ & $\begin{array}{c}0.01 \pm \\
0.0\end{array}$ \\
\hline 12.62 & 256,354 & 463 & $\mathrm{MS}^{2}: 301$ (100) & Quercetin-3-O-glucoside ${ }^{\mathrm{a}, \mathrm{b}, \mathrm{f}}$ & $\begin{array}{c}0.01 \pm \\
0.0\end{array}$ & ND & ND & ND & ND & $\begin{array}{c}0.02 \pm \\
0.0\end{array}$ \\
\hline 13.31 & 256,353 & 549 & $\begin{array}{c}\mathrm{MS}^{2}: 505(100) ; \mathrm{MS}^{3}: \\
301(100), 300(28) \\
463(26)\end{array}$ & $\begin{array}{l}\text { Quercetin-O-malonyl } \\
\text { hexoside }^{\mathrm{a}, \mathrm{j}}\end{array}$ & ND & ND & ND & ND & $\begin{array}{c}0.01 \pm \\
0.0\end{array}$ & $\begin{array}{c}0.07 \pm \\
0.0\end{array}$ \\
\hline
\end{tabular}


Table 2. Cont.

\begin{tabular}{|c|c|c|c|c|c|c|c|c|c|c|}
\hline \multirow{2}{*}{$\begin{array}{c}t_{R} \\
(\min )\end{array}$} & \multirow{2}{*}{$\begin{array}{l}\lambda_{\max } \\
(\mathrm{nm})\end{array}$} & \multirow{2}{*}{$\begin{array}{c}{[\mathrm{M}-\mathrm{H}]^{-}} \\
m / z\end{array}$} & \multirow{2}{*}{ MS $^{n}$ (\% Base Peak) } & \multirow{2}{*}{ Proposed Compound } & \multicolumn{6}{|c|}{ mg/g Raw Sample } \\
\hline & & & & & BP-A1 & BP-A2 & BP-A3 & BB-A1 & BB-A2 & BB-A3 \\
\hline 13.61 & 270 & 477 & $\begin{array}{l}\mathrm{MS}^{2}: 315 \text { (100), } 462 \\
(42), 300(14) ; \mathrm{MS}^{3}: \\
300(100)\end{array}$ & $\begin{array}{c}\text { Methyl } \\
\text { herbacetin-3-O-hexoside }^{\text {a,c }}\end{array}$ & ND & ND & ND & $\begin{array}{l}0.04 \pm \\
0.0\end{array}$ & ND & ND \\
\hline 14.06 & 265,347 & 447 & $\mathrm{MS}^{2}: 285$ (100), $284(80)$ & Kaempferol-O-hexoside ${ }^{\mathrm{a}, \mathrm{k}}$ & ND & ND & ND & ND & $\begin{array}{c}0.03 \pm \\
0.0\end{array}$ & $\begin{array}{c}0.16 \pm \\
0.0\end{array}$ \\
\hline 14.18 & 254,347 & 447 & $\mathrm{MS}^{2}: 301$ (100) & $\begin{array}{l}\text { Quercetin-3-O- } \\
\text { rhamnoside }^{\mathrm{a}, \mathrm{b}, \mathrm{e}}\end{array}$ & ND & ND & $\begin{array}{c}0.81 \pm \\
0.0\end{array}$ & ND & ND & ND \\
\hline 14.31 & 254,355 & 477 & $\mathrm{MS}^{2}: 314(100), 315(45)$ & Isorhamnetin-O-hexoside ${ }^{\mathrm{a}, \mathrm{k}}$ & ND & ND & ND & ND & $\begin{array}{c}0.01 \pm \\
0.0\end{array}$ & $\begin{array}{c}0.01 \pm \\
0.0\end{array}$ \\
\hline 14.44 & 255,354 & 563 & $\begin{array}{c}\text { MS²: }^{519} \text { (100); } \text { MS }^{3}: \\
315 \text { (100) }\end{array}$ & $\begin{array}{l}\text { Isorhamnetin-3-O-malonyl } \\
\text { glucoside }\end{array}$ & ND & ND & $\begin{array}{c}0.06 \pm \\
0.0\end{array}$ & ND & ND & ND \\
\hline 14.73 & 277,311 & 301 & $\mathrm{MS}^{2}: 283(100), 286(40)$ & Hesperetin ${ }^{\mathrm{a}, \mathrm{b}}$ & ND & ND & $\begin{array}{c}0.05 \pm \\
0.0\end{array}$ & ND & ND & ND \\
\hline 14.99 & 265,345 & 533 & $\begin{array}{c}\mathrm{MS}^{2}: 489(100) ; \mathrm{MS}^{3}: \\
285(100)\end{array}$ & $\begin{array}{l}\text { Kaempferol-O-malonyl } \\
\text { hexoside }^{\mathrm{a}, \mathrm{h}}\end{array}$ & ND & ND & ND & ND & $\begin{array}{c}0.07 \pm \\
0.0\end{array}$ & $\begin{array}{c}0.09 \pm \\
0.0\end{array}$ \\
\hline 15.39 & 299,308 & 436 & $\mathrm{MS}^{2}: 316(100)$ & Di- $p$-coumaroylspermidine ${ }^{\mathrm{a}, \mathrm{i}}$ & $\begin{array}{c}0.72 \pm \\
0.0\end{array}$ & $\begin{array}{c}0.20 \pm \\
0.0\end{array}$ & ND & ND & ND & ND \\
\hline 15.76 & 295,315 & 630 & $\begin{array}{l}\mathrm{MS}^{2}: 468(100), 494 \\
(84), 358(7) ; \mathrm{MS}^{3}: \\
332(100)\end{array}$ & $\begin{array}{c}N^{1}, N^{5}, \\
N^{10} \text {-tri-caffeoylspermidine } \\
\substack{\mathrm{a}, \mathrm{d}, \mathrm{g} \\
\text { end }}\end{array}$ & ND & ND & ND & $\begin{array}{l}0.20 \pm \\
0.0\end{array}$ & $\begin{array}{l}0.50 \pm \\
0.0\end{array}$ & ND \\
\hline 16.18 & 264,341 & 431 & $\mathrm{MS}^{2}: 285(100)$ & Kaempferol-3-O-rhamnoside & ND & ND & $\begin{array}{c}0.04 \pm \\
0.0\end{array}$ & ND & ND & ND \\
\hline 16.64 & 255,354 & 461 & $\begin{array}{l}\mathrm{MS}^{2}: 314(100), 315 \\
\quad(77), 299(39)\end{array}$ & $\begin{array}{l}\text { Isorhamnetin-O- } \\
\text { deoxyhexoside } \\
\mathrm{a}, \mathrm{c}\end{array}$ & ND & ND & $\begin{array}{c}0.31 \pm \\
0.0\end{array}$ & ND & ND & ND \\
\hline 16.75 & 296,319 & 630 & $\begin{array}{c}\mathrm{MS}^{2}: 468(100), 494 \\
(86), 358(7) ; \mathrm{MS}^{3}: 332 \\
(100)\end{array}$ & $\begin{array}{c}N^{1}, N^{5}, \\
N^{10} \text {-tri-caffeoylspermidine } \\
\substack{\mathrm{a}, \mathrm{d}, \mathrm{g} \\
\text { a }}\end{array}$ & $\begin{array}{c}0.43 \pm \\
0.0\end{array}$ & $\begin{array}{c}0.08 \pm \\
0.0\end{array}$ & ND & $\begin{array}{c}1.53 \pm \\
0.0\end{array}$ & $\begin{array}{c}4.15 \pm \\
0.0\end{array}$ & $\begin{array}{c}0.51 \pm \\
0.0\end{array}$ \\
\hline 17.57 & 293,314 & 644 & $\begin{array}{c}\mathrm{MS}^{2}: 358(11), 482(11) \\
508 \text { (100); MS } 3 \text { : } 332 \\
(27), 358(100), 372(49)\end{array}$ & $\begin{array}{c}N^{1} \text {-feruloyl- } N^{5}, \\
N^{10} \text {-dicaffeoylspermidine }{ }^{\text {a,d,e }}\end{array}$ & ND & ND & ND & ND & $\begin{array}{c}0.04 \pm \\
0.0\end{array}$ & ND \\
\hline 18.09 & 295,311 & 614 & $\begin{array}{l}\text { MS }^{2}: 494(25), 478 \\
(100), 452(69), 358(20)\end{array}$ & $\begin{array}{c}N^{1} \text {-p-coumaroyl- } N^{5}, \\
N^{10} \text {-dicaffeoylspermidine a,e }\end{array}$ & $\begin{array}{c}0.21 \pm \\
0.0\end{array}$ & ND & $\begin{array}{c}0.38 \pm \\
0.0\end{array}$ & $\begin{array}{c}0.16 \pm \\
0.0\end{array}$ & $\begin{array}{c}0.13 \pm \\
0.0\end{array}$ & $\begin{array}{c}0.07 \pm \\
0.0\end{array}$ \\
\hline 18.18 & 299,308 & 478 & $\begin{array}{l}\mathrm{MS}^{2}: 358(100), 332 \\
(12), 145(5)\end{array}$ & $\begin{array}{l}N^{1} \text {-acetyl- } N^{\frac{1}{5}}, N^{10}-d i-p \text { - } \\
\text { coumaroylspermidine } \\
\text { a,f }\end{array}$ & $\begin{array}{c}2.83 \pm \\
0.1\end{array}$ & $\begin{array}{c}0.69 \pm \\
0.0\end{array}$ & ND & ND & ND & ND \\
\hline 18.74 & 295,311 & 614 & $\begin{array}{l}\mathrm{MS}^{2}: 478(100), 468 \\
(20), 452(68), 342(5)\end{array}$ & $\begin{array}{c}N^{1} \text {-p-coumaroyl- } N^{5} \\
N^{10} \text {-dicaffeoylspermidine } \\
\text { (isomer) }^{\mathrm{a}, \mathrm{e}}\end{array}$ & ND & ND & ND & $\begin{array}{c}0.06 \pm \\
0.0\end{array}$ & $\begin{array}{c}0.20 \pm \\
0.0\end{array}$ & ND \\
\hline 19.34 & 295,311 & 614 & $\begin{array}{c}\mathrm{MS}^{2}: 494(24), 478 \\
(100), 452(76), 358(22)\end{array}$ & $\begin{array}{c}N^{1}-p \text {-coumaroyl- } N^{5} \\
N^{10} \text {-dicaffeoylspermidine } \\
\text { (isomer) }^{\mathrm{a}, \mathrm{e}}\end{array}$ & ND & ND & $\begin{array}{c}1.36 \pm \\
0.0\end{array}$ & $\begin{array}{l}0.76 \pm \\
0.0\end{array}$ & $\begin{array}{l}1.98 \pm \\
0.0\end{array}$ & $\begin{array}{c}0.89 \pm \\
0.0\end{array}$ \\
\hline 20.02 & 295,318 & 644 & $\begin{array}{c}\mathrm{MS}^{2}: 358(8), 482(75) \\
508 \text { (100); } \mathrm{MS}^{3}: 332 \\
(27), 358(100), 372(49)\end{array}$ & $\begin{array}{c}N^{1} \text {-feruloyl- } N^{5}, \\
N^{10} \text {-dicaffeoylspermidine } \\
{\text { (isomer) }{ }^{\mathrm{a}, \mathrm{d}, \mathrm{g}}}^{\text {(iso }^{2}}\end{array}$ & ND & ND & ND & ND & $\begin{array}{l}0.18 \pm \\
0.0\end{array}$ & ND \\
\hline 20.27 & 295,310 & 598 & $\begin{array}{c}\mathrm{MS}^{2}: 478(46), 462 \\
(100), 452(46), 342(14)\end{array}$ & $\begin{array}{l}N^{1}, N^{5} \text {-di-p-coumaroyl- } N^{10}- \\
\text { caffeoylspermidine } \\
\text { a,e }\end{array}$ & ND & ND & ND & $\begin{array}{l}0.22 \pm \\
0.0\end{array}$ & $\begin{array}{c}0.08 \pm \\
0.0\end{array}$ & ND \\
\hline 21.23 & 295,310 & 582 & $\begin{array}{c}\mathrm{MS}^{2}: 462(100), 436(9), \\
342(7)\end{array}$ & $\begin{array}{l}N^{1}, N^{5}, N^{10} \text {-tri-p- } \\
\text { coumaroylspermidine }\end{array}$ & ND & $\begin{array}{c}0.13 \pm \\
0.0\end{array}$ & ND & $\begin{array}{c}0.69 \pm \\
0.0\end{array}$ & $\begin{array}{c}1.02 \pm \\
0.0\end{array}$ & $\begin{array}{c}0.42 \pm \\
0.0\end{array}$ \\
\hline 21.33 & $\begin{array}{l}254 \\
268 s h \\
348\end{array}$ & 285 & $\mathrm{MS}^{2}: 285$ (100) & Luteolin ${ }^{a, b}$ & ND & ND & $\begin{array}{c}1.00 \pm \\
0.0\end{array}$ & ND & ND & ND \\
\hline 22.22 & 294,309 & 598 & $\begin{array}{c}\mathrm{MS}^{2}: 462(100), 478 \\
(39), 452(34), 342(14)\end{array}$ & $\begin{array}{c}N^{1}, N^{5} \text {-di-p-coumaroyl- } N^{10}- \\
\text { caffeoylspermidine } \\
\text { a,d,g }\end{array}$ & $\begin{array}{c}0.21 \pm \\
0.0\end{array}$ & $\begin{array}{c}0.48 \pm \\
0.0\end{array}$ & $\begin{array}{c}1.16 \pm \\
0.0\end{array}$ & $\begin{array}{c}1.40 \pm \\
0.0\end{array}$ & $\begin{array}{c}2.12 \pm \\
0.0\end{array}$ & $\begin{array}{c}0.85 \pm \\
0.0\end{array}$ \\
\hline 22.73 & 295,310 & 582 & $\begin{array}{c}\mathrm{MS}^{2}: 462(100), 436(9), \\
342(7)\end{array}$ & $\begin{array}{c}N^{1}, N^{5}, N^{10} \text {-tri-p- } \\
\text { coumaroylspermidine } \\
\text { a,e }\end{array}$ & ND & $\begin{array}{l}0.16 \pm \\
0.0\end{array}$ & ND & $\begin{array}{l}1.82 \pm \\
0.0\end{array}$ & $\begin{array}{c}2.84 \pm \\
0.0\end{array}$ & $\begin{array}{c}1.68 \pm \\
0.0\end{array}$ \\
\hline 22.77 & 295,310 & 598 & $\begin{array}{l}\mathrm{MS}^{2}: 342(13), 452(32), \\
\quad 462(100), 478(37)\end{array}$ & $\begin{array}{l}N^{1}, N^{5} \text {-di-p-coumaroyl- } N^{10}- \\
\text { caffeoylspermidine (isomer) }\end{array}$ & ND & ND & $\begin{array}{c}2.61 \pm \\
0.1\end{array}$ & ND & ND & ND \\
\hline 24.12 & 295,310 & 582 & $\begin{array}{c}\mathrm{MS}^{2}: 462(100), 436(9), \\
342(6)\end{array}$ & $\begin{array}{c}N^{1}, N^{5}, N^{10} \text {-tri-p- } \\
\text { coumaroylspermidine }\end{array}$ & $\begin{array}{l}0.14 \pm \\
0.0\end{array}$ & $\begin{array}{c}0.18 \pm \\
0.0\end{array}$ & $\begin{array}{c}0.61 \pm \\
0.0\end{array}$ & $\begin{array}{c}2.13 \pm \\
0.0\end{array}$ & $\begin{array}{c}3.20 \pm \\
0.0\end{array}$ & $\begin{array}{c}0.93 \pm \\
0.0\end{array}$ \\
\hline 25.08 & 295,310 & 582 & $\begin{array}{c}\mathrm{MS}^{2}: 462(100), 436(9), \\
342(7)\end{array}$ & $\begin{array}{c}N^{1}, N^{5}, N^{10} \text {-tri-p- } \\
\underset{\mathrm{a}, \mathrm{e}}{\text { coumaroylspermidine }}\end{array}$ & ND & ND & $\begin{array}{c}0.20 \pm \\
0.0\end{array}$ & $\begin{array}{c}0.77 \pm \\
0.0\end{array}$ & $\begin{array}{c}1.12 \pm \\
0.1\end{array}$ & $\begin{array}{c}0.34 \pm \\
0.0\end{array}$ \\
\hline 26.47 & 295,305 & 582 & $\begin{array}{c}\mathrm{MS}^{2}: 342(100), 436(9) \\
462(100)\end{array}$ & $\begin{array}{l}N^{1}, N^{5}, N^{10} \text {-tri- } p \text { - } \\
\text { coumaroylspermidine } \\
\text { (isomer) }^{\mathrm{a}, \mathrm{e}}\end{array}$ & $\begin{array}{c}0.55 \pm \\
0.0\end{array}$ & $\begin{array}{c}0.29 \pm \\
0.0\end{array}$ & $\begin{array}{c}6.28 \pm \\
0.0\end{array}$ & $\begin{array}{c}8.47 \pm \\
0.0\end{array}$ & $\begin{array}{l}15.23 \\
\pm 0.1\end{array}$ & $\begin{array}{c}5.33 \pm \\
0.0\end{array}$ \\
\hline 26.92 & 270 & 785 & $\begin{array}{l}\mathrm{MS}^{2}: 665 \text { (100), } 545 \\
(14), 639(13) ; \mathrm{MS}^{3}: \\
545(100)\end{array}$ & Tetracoumaroyl spermine ${ }^{\mathrm{a}, \mathrm{l}}$ & ND & $\begin{array}{c}3.34 \pm \\
0.0\end{array}$ & ND & ND & ND & ND \\
\hline
\end{tabular}


Table 2. Cont.

\begin{tabular}{|c|c|c|c|c|c|c|c|c|c|c|}
\hline \multirow{2}{*}{$t_{R}(\min )$} & \multirow{2}{*}{$\begin{array}{l}\lambda_{\max } \\
(\mathrm{nm})\end{array}$} & \multirow{2}{*}{$\begin{array}{c}{[\mathrm{M}-\mathrm{H}]^{-}} \\
\mathrm{m} / \mathrm{z}\end{array}$} & \multirow{2}{*}{ MS $^{n}$ (\% Base Peak) } & \multirow{2}{*}{ Proposed Compound } & \multicolumn{6}{|c|}{ mg/g Raw Sample } \\
\hline & & & & & BP-A1 & BP-A2 & BP-A3 & BB-A1 & BB-A2 & BB-A3 \\
\hline 27.52 & 295,308 & 612 & $\begin{array}{l}\mathrm{MS}^{2}: 492(100) ; \mathrm{MS}^{3}: \\
372(100), 449(24)\end{array}$ & $\begin{array}{l}\text { Feruloyl dicoumaroyl } \\
\text { spermidine }{ }^{a, 1}\end{array}$ & ND & ND & $\begin{array}{c}0.93 \pm \\
0.0\end{array}$ & $\begin{array}{c}0.32 \pm \\
0.0\end{array}$ & $\begin{array}{c}0.70 \pm \\
0.0\end{array}$ & ND \\
\hline 27.67 & 271 & 315 & $\begin{array}{c}\mathrm{MS}^{2}: 300(100) ; \mathrm{MS}^{3}: \\
272(100), 255(54) \\
165(26)\end{array}$ & $\begin{array}{c}\text { Herbacetin-methyl- } \\
\text { ether } \\
\text { a }\end{array}$ & ND & ND & ND & ND & ND & $\begin{array}{c}0.11 \pm \\
0.0\end{array}$ \\
\hline 28.55 & $\begin{array}{c}280 \\
307 \mathrm{sh}\end{array}$ & 785 & $\begin{array}{c}\mathrm{MS}^{2}: 665(100), 545 \\
(13), 639(13) ; \mathrm{MS}^{3}: \\
545(100)\end{array}$ & $\begin{array}{c}\text { Tetracoumaroyl } \\
\text { spermine (isomer) }{ }^{a, 1}\end{array}$ & $\begin{array}{c}0.90 \pm \\
0.0\end{array}$ & $\begin{array}{c}8.25 \pm \\
0.1\end{array}$ & $\begin{array}{c}0.76 \pm \\
0.0\end{array}$ & $\begin{array}{l}0.42 \pm \\
0.0\end{array}$ & $\begin{array}{c}0.31 \pm \\
0.0\end{array}$ & ND \\
\hline 28.77 & 266,365 & 285 & $\mathrm{MS}^{2}: 285(100)$ & Kaempferol ${ }^{\mathrm{a}, \mathrm{b}}$ & ND & ND & ND & ND & ND & $\begin{array}{c}0.28 \pm \\
0.0\end{array}$ \\
\hline 29.28 & $\begin{array}{l}277 \\
310 \text { sh }\end{array}$ & 785 & $\begin{array}{l}\text { MS² }^{2} 665 \text { (100), } 545 \\
(13), 639 \text { (13); } \text { MS }^{3}: \\
545 \text { (100) }\end{array}$ & $\begin{array}{c}\text { Tetracoumaroyl } \\
\text { spermine (isomer) }{ }^{a, 1}\end{array}$ & ND & $\begin{array}{c}0.83 \pm \\
0.1\end{array}$ & ND & ND & ND & ND \\
\hline 29.57 & 295,318 & 672 & - & $\underset{\mathrm{a}, \mathrm{e}}{\text { Polyamide derivative }}$ & ND & ND & $\begin{array}{c}1.70 \pm \\
0.0\end{array}$ & ND & ND & ND \\
\hline 30.28 & $\begin{array}{c}289 \\
306 s h\end{array}$ & 785 & $\begin{array}{l}\text { MS'2 }:^{2} 655 \text { (100), } 545 \\
(13), 639 \text { (13); } \text { MS }^{3}: \\
545 \text { (100) }\end{array}$ & $\begin{array}{c}\text { Tetracoumaroyl } \\
\text { spermine (isomer) }{ }^{a, 1}\end{array}$ & $\begin{array}{l}0.74 \pm \\
0.0\end{array}$ & $\begin{array}{c}9.11 \pm \\
0.1\end{array}$ & ND & $\begin{array}{l}0.50 \pm \\
0.0\end{array}$ & ND & ND \\
\hline 31.92 & 293,310 & 785 & $\begin{array}{l}\mathrm{MS}^{2}: 665 \text { (100), } 545 \\
(13), 639 \text { (13); } \mathrm{MS}^{3}: \\
545 \text { (100) }\end{array}$ & $\begin{array}{c}\text { Tetracoumaroyl } \\
\text { spermine (isomer) }{ }^{\mathrm{a}, 1}\end{array}$ & $\begin{array}{c}0.50 \pm \\
0.0\end{array}$ & $\begin{array}{c}6.51 \pm \\
0.1\end{array}$ & ND & $\begin{array}{c}0.47 \pm \\
0.0\end{array}$ & ND & $\begin{array}{c}0.36 \pm \\
0.0\end{array}$ \\
\hline 33.97 & 299,310 & 785 & $\begin{array}{l}\mathrm{MS}^{2}: 665(100), 545 \\
(13), 639(13) ; \mathrm{MS}^{3}: \\
545(100)\end{array}$ & $\begin{array}{c}\text { Tetracoumaroyl } \\
\text { spermine (isomer) }{ }^{a, 1}\end{array}$ & $\begin{array}{l}0.70 \pm \\
0.0\end{array}$ & $\begin{array}{c}8.49 \pm \\
0.1\end{array}$ & ND & $\begin{array}{l}0.86 \pm \\
0.0\end{array}$ & $\begin{array}{c}0.36 \pm \\
0.1\end{array}$ & ND \\
\hline \multirow{2}{*}{\multicolumn{4}{|c|}{$\begin{array}{l}\text { Total amount of phenolic compounds } \\
\text { Total amount of phenylamides }\end{array}$}} & & 0.5 & 0.1 & 2.6 & 0.6 & 0.6 & 1.0 \\
\hline & & & & & 7.9 & 38.7 & 15.9 & 20.8 & 34.2 & 11.4 \\
\hline
\end{tabular}

Confirmed with: ${ }^{a} \mathrm{MS}^{\mathrm{n}}$ fragmentation; ${ }^{\mathrm{b}}$ Standard; References: ${ }^{\mathrm{c}}$ [10]; ${ }^{\mathrm{d}}$ [6]; ${ }^{\mathrm{e}}$ [9]; ${ }^{\mathrm{f}}$ [27]; ${ }^{\mathrm{g}}$ [28]; ${ }^{\mathrm{h}}$ [29]; ${ }^{\mathrm{i}}$ [30]; ${ }^{\mathrm{j}}$ [31]; ${ }^{\mathrm{k}}$ [32]; ${ }^{\mathrm{l}}$ [33]. Values expressed as $\mathrm{mg}$ of each compound/g sample. $\mathrm{ND}=$ not detected.

Within the phenolic compounds, flavonol derivatives such as quercetin, kaempferol, isorhamnetin and herbacetin glycosides, where the main compounds in both bee pollen and bee bread samples. These flavonoids have also been observed in many reported studies for the phenolic content of both bee products and were used for confirming our results $[6,9,10,28]$. A few flavonoids such as kaempferol-O-rutinoside $(m / z 593)$, quercetin3-O-glucoside $(m / z 463)$, quercetin-3-O-rhamnoside $(m / z 447)$, hesperetin $(m / z 301)$ and luteolin $(m / z 285)$ were identified considering the retention time, UV-Vis profile and MS pattern of the commercial standards.

The identification of the other phytochemicals was done through interpretation of the fragmentation pathways detected in $\mathrm{MS}^{\mathrm{n}}$ spectra, comparing with that available in the literature and combining with the spectral information from UV.

All the extracts typically contained flavonoid glycosides in their composition. The sugar moieties in the flavonoids were assigned to rutinosides, hexosides, glucosides and rhamnosides. These are the most common and frequent in nature and were also confirmed in these samples. Methyl herbacetin-O-dihexoside $(m / z 639)$, isorhamnetin-O-pentosyl-hexoside ( $m / z$ 609), kaempferol-3-O-rutinoside $(m / z 593)$ and quercetin-3-O-glucoside $(m / z 463)$ were identified as the most common compounds in both bee pollen and bee bread samples. BP-A3 sample was the richest among all in terms of diversity of flavonoids, at the same time it had the highest flavonoid content with a value of $2.70 \mathrm{mg} / \mathrm{g}$. Quercetin-3-O-rhamnoside $(\mathrm{m} / \mathrm{z} 447)$, isorhamnetin-O-deoxyhexoside $(\mathrm{m} / \mathrm{z} 461)$ and luteolin $(\mathrm{m} / \mathrm{z} 447)$ were only assigned in the BP-A3 sample and were the major compounds contributing to its high flavonoid content. In bee bread samples, the flavonoid content was higher than BP-A1 and BP-A2, with a great diversity of substances in different amounts, particularly, herbacetin derivatives such as methyl herbacetin-O-rutinoside $(\mathrm{m} / \mathrm{z} 623)$, methyl herbacetin-3-Ohexoside $(m / z 447)$ and methyl herbacetin $(m / z 315)$. This assignment was supported by previous identification of similar compounds in bee pollen and bee bread samples from Brassicaceae spp., Asteraceae spp., Lavandula spp. and Plantago spp. plant family [10,34,35].

This study enabled also the identification of an important group of compounds present in high concentrations in the bee pollen and bee bread samples, namely phenylamides and their derivatives. Phenylamides are low-molecular products of covalent bonding between carboxylic groups of hydroxycinnamic acids and amine groups of aliphatic di- 
and polyamines or aromatic monoamines [36]. In both, bee pollen and bee bread samples, the most widely distributed acidic parent compounds of phenylamides were caffeic, ferulic and $p$-coumaric acids, while the aliphatic polyamines spermidine and spermine were found as the predominant amine components of phenylamides. For the spermidines, the formation of the amide linkage between a phenylamide and the phenolic acid can occur in the $N^{1}, N^{5}$ and $N^{10}$ positions [36]. Spermine are mostly found conjugated with coumaroyl moieties in the positions $N^{1}, N^{5}, N^{10}$ and $N^{4}$. These polyamine conjugated with phenolic compounds have a predominance in the plant species of several families such as Fabaceae, Asteraceae, Amaryllidaceae and Araceae [37].

The content of phenylamides varied broadly between 7.9 and $38.7 \mathrm{mg} / \mathrm{g}$, for BP-A1 and BPA2, respectively. $N^{1}$-acetyl- $N^{5}, N^{10}-d i$-p-coumaroylspermidine $(m / z 478), N^{1}, N^{5}$-di-pcoumaroyl- $N^{10}$-caffeoylspermidine $(m / z 598), N^{1}, N^{5}$-di-p-coumaroyl- $N^{10}$-caffeoylspermidine $(m / z 598)$, tetracoumaroyl spermine $(m / z 785)$ and its isomers $(m / z 785)$ were detected at different concentrations in all three bee pollen samples at very high levels. In bee bread samples, tetracoumaroyl spermine and its isomers were found in lower concentrations compared to bee pollen. However, bee bread samples exhibited a rich profile especially in respect to $N^{1}, N^{5}, N^{10}$-tri-caffeoylspermidine $(m / z 630), N^{1}, N^{5}, N^{10}$-tri-pcoumaroylspermidine $(m / z 582)$ and $N^{1}, N^{5}, N^{10}$-tri-p-coumaroylspermidine (isomer) $(\mathrm{m} / z$ 582 ), which can be related to the botanical origin of the samples. In the study conducted by Urcan et al. [35], it was found that bee bread with origin in pollens from plant families such as Asteraceae and Fabaceae have a predominance of phenylamides.

The effect of in vitro gastrointestinal digestion on the stability of phenolic compounds and phenylamides is given in Tables 3 and 4 . Accordingly, after the oral phase, the bioactive compounds in the BP-A1, BP-A2 and BP-A3 samples decreased by $54 \%, 92 \%$ and $7 \%$, respectively. Among the bee bread samples, the highest decrease was in BB-A3 (25\%), followed by BB-A2 (17\%) and BB-A1 (4\%). Despite these decreases were statistically significant $(p<0.05)$, they were not very high for BP-A3, BB-A1 and BB-A2. This may be due to contact with the enzyme or short digestion time [38]. These reductions were comparable to the phenolic compound results reported by Quan et al. [23] and LucasGonzalez et al. [38] for different food matrices.

Compared with the oral phase, the phenolic content in all samples was significantly $(p<0.05)$ reduced at the end of the gastric phase. While the content of isorhamnetin-Opentosyl-hexoside $(m / z 609)$ in the raw BP-A1 and BP-A2 samples was 0.22 and $0.07 \mathrm{mg} / \mathrm{g}$, respectively, its concentration in both samples decreased to a minimum of $0.05 \mathrm{mg} / \mathrm{g}$ after the gastric phase. A significant decreasing trend was also observed in the BP-A3 phenolic and phenylamide compounds when comparing to the other two bee pollen samples. For the bee bread samples, a similar decrease was observed on the phenolic content at the end of the gastric phase, presenting bee bread, except for BB-A3 sample, a richer phenolic content when comparing to the bee pollen samples. As mentioned by some authors earlier [20,26], the decrease in the concentration of the phenolic compounds and phenylamides during bee pollen and bee bread digestion could be explained by the interaction with other food ingredients, causing changes in their molecular weights, solubility and chemical structures. Moreover, hydrolysis of the released compounds, mainly as a result of acidic $\mathrm{pH}(\mathrm{pH} 2-3)$ and enzymatic activity, may have another important effect on this decrease [22].

In the intestinal phase, Tables 3 and 4, there was a slight increase in the phenolic content of BP-A1 and BP-A3, while no change was observed in the BP-A2 content. On the other hand, there was a significant decrease in the phenolic content of all bee bread samples, especially in BB-A1 and BB-A2. Partial decreases and increases in the concentration of phenolic compounds after the intestinal phase could be attributed to the instability of these compounds under alkaline conditions and their possible interactions with other food components like protein, lipid or fiber, as in the gastric phase [19,20]. Besides, phenylamides are known to be completely digested and absorbed in the intestine [39], and our findings show that the identified phenylamides in the samples were completely digested after the intestinal phase. In the calculation based on the total amount of phenolic compounds 
found in the samples, BP-A2 had the highest bioaccessibility score with a rate of $57 \%$, followed by BB-A1 $(35 \%)>$ BB-A2 $(28 \%)>$ BP-A1 $(24 \%)>$ BP-A3 $(17 \%)>$ BB-A3 $(11 \%)$. After in vitro gastrointestinal digestion, the available quantity and diversity of compounds varied significantly $(p<0.05)$ depending on the tested sample.

The differences observed in the bioavailability values are due to the diversified chemical structures found in both phenolic and phenylamide compounds, which can range from simple to highly polymerized molecules. Different conditions (enzymatic activity and/or $\mathrm{pH}$ changes) of gastrointestinal digestion cause various changes in the phenol structure such as hydroxylation, methylation, isoprenylation, dimerization and glycosylation, and consequently affect the stability and bioaccessibility of these compounds [19,38].

Table 3. Phenolic and phenylamide compounds of the bee pollen samples obtained after each in vitro digestion phase.

\begin{tabular}{|c|c|c|c|c|c|c|c|c|c|}
\hline \multirow{2}{*}{ Compound } & \multicolumn{3}{|c|}{ Mouth } & \multicolumn{3}{|c|}{ Stomach } & \multicolumn{3}{|c|}{ Intestine } \\
\hline & BP-A1 & BP-A2 & BP-A3 & BP-A1 & BP-A2 & BP-A3 & BP-A1 & BP-A2 & BP-A3 \\
\hline $\begin{array}{l}\text { Quercetin- } O \text {-hexosyl-O- } \\
\text { rutinoside }\end{array}$ & $0.03 \pm 0.0$ & ND & ND & ND & ND & ND & ND & ND & ND \\
\hline Quercetin-diglucoside & ND & ND & $0.03 \pm 0.0$ & ND & ND & $0.04 \pm 0.0$ & ND & ND & $0.05 \pm 0.0$ \\
\hline Methyl herbacetin-O-dihexoside & $0.03 \pm 0.0$ & ND & $0.32 \pm 0.0$ & ND & ND & $0.17 \pm 0.0$ & ND & ND & $0.22 \pm 0.0$ \\
\hline Kaempferol-O-dihexoside & $0.05 \pm 0.0$ & ND & ND & ND & ND & ND & ND & ND & ND \\
\hline $\begin{array}{l}\text { Isorhamnetin-O-pentosyl- } \\
\text { hexoside }\end{array}$ & $0.12 \pm 0.0$ & $0.06 \pm 0.0$ & ND & $0.05 \pm 0.0$ & $0.05 \pm 0.0$ & ND & $0.09 \pm 0.0$ & $0.04 \pm 0.0$ & ND \\
\hline Kaempferol-3-O-rutinoside & $0.01 \pm 0.0$ & $0.00 \pm 0.0$ & $0.03 \pm 0.0$ & ND & ND & $0.01 \pm 0.0$ & $0.01 \pm 0.0$ & ND & $0.01 \pm 0.0$ \\
\hline Quercetin-3-O-glucoside & $0.01 \pm 0.0$ & ND & ND & ND & ND & ND & $0.01 \pm 0.0$ & ND & ND \\
\hline Quercetin-3-O-rhamnoside & ND & ND & $0.77 \pm 0.0$ & ND & ND & $0.15 \pm 0.0$ & ND & ND & $0.14 \pm 0.0$ \\
\hline $\begin{array}{l}\text { Isorhamnetin-3-O-malonyl } \\
\text { glucoside }\end{array}$ & ND & ND & $0.03 \pm 0.0$ & ND & ND & $0.01 \pm 0.0$ & ND & ND & ND \\
\hline Hesperetin & ND & ND & $0.05 \pm 0.0$ & ND & ND & ND & ND & ND & ND \\
\hline Di-p-coumaroylspermidine & $0.77 \pm 0.0$ & $0.03 \pm 0.0$ & ND & ND & ND & ND & ND & ND & ND \\
\hline Kaempferol-3-O-rhamnoside & ND & ND & $0.03 \pm 0.0$ & ND & ND & ND & ND & ND & ND \\
\hline Isorhamnetin- $O$-deoxyhexoside & ND & ND & $0.31 \pm 0.0$ & ND & ND & $0.02 \pm 0.0$ & ND & ND & $0.02 \pm 0.0$ \\
\hline $\begin{array}{c}N^{1}, N^{5} \\
N^{10} \text {-tri-caffeoylspermidine }\end{array}$ & $0.26 \pm 0.0$ & $0.04 \pm 0.0$ & ND & ND & ND & ND & ND & ND & ND \\
\hline $\begin{array}{c}N^{1} \text {-acetyl- } N^{5} \\
N^{10} \text {-di-p-coumaroylspermidine }\end{array}$ & $2.01 \pm 0.1$ & $0.35 \pm 0.0$ & ND & ND & ND & ND & ND & ND & ND \\
\hline $\begin{array}{c}N^{1}-p \text {-coumaroyl- } N^{5} \\
N^{10} \text {-dicaffeoylspermidine } \\
N^{1}-p \text {-coumaroyl- } N^{5}\end{array}$ & $0.14 \pm 0.0$ & ND & $0.39 \pm 0.0$ & ND & ND & ND & ND & ND & ND \\
\hline $\begin{array}{c}N^{10} \text {-dicaffeoylspermidine } \\
\text { (isomer) }\end{array}$ & ND & ND & $1.16 \pm 0.0$ & ND & ND & ND & ND & ND & ND \\
\hline $\begin{array}{l}N^{1}, N^{5}-d i-p \text {-coumaroyl- } N^{10} \\
\text { caffeoylspermidine }\end{array}$ & $0.10 \pm 0.0$ & $0.22 \pm 0.0$ & $1.17 \pm 0.0$ & ND & ND & ND & ND & ND & ND \\
\hline $\begin{array}{c}N^{1}, N^{5} \text {-di-p-coumaroyl- } N^{10}- \\
\text { caffeoylspermidine } \\
\text { (isomer) }\end{array}$ & ND & ND & $1.97 \pm 0.1$ & ND & ND & ND & ND & ND & ND \\
\hline Luteolin & ND & ND & $0.99 \pm 0.0$ & ND & ND & ND & ND & ND & ND \\
\hline $\begin{array}{c}N^{1}, N^{5}, \\
N^{10} \text {-tri-p-coumaroylspermidine }\end{array}$ & ND & $0.11 \pm 0.0$ & $0.56 \pm 0.0$ & ND & ND & ND & ND & ND & ND \\
\hline $\begin{array}{c}N^{1}, N^{5}, \\
N^{10} \text {-tri-p-coumaroylspermidine } \\
\text { (isomer) }\end{array}$ & $0.43 \pm 0.0$ & $0.22 \pm 0.0$ & $6.31 \pm 0.1$ & ND & ND & ND & ND & ND & ND \\
\hline Tetracoumaroyl spermine & ND & ND & ND & ND & $0.18 \pm 0.0$ & ND & ND & ND & ND \\
\hline Feruloyl dicoumaroyl spermidine & ND & ND & $0.75 \pm 0.0$ & ND & ND & ND & ND & ND & ND \\
\hline $\begin{array}{l}\text { Tetracoumaroyl spermine } \\
\text { (isomer) }\end{array}$ & ND & $0.95 \pm 0.0$ & ND & ND & ND & ND & ND & ND & ND \\
\hline $\begin{array}{l}\text { Diferuloyl coumarouyl } \\
\text { spermidine }\end{array}$ & $0.75 \pm 0.0$ & ND & ND & ND & ND & ND & ND & ND & ND \\
\hline Polyamide derivative & ND & ND & $3.12 \pm 0.2$ & ND & ND & ND & ND & ND & ND \\
\hline $\begin{array}{l}\text { Tetracoumaroyl spermine } \\
\text { (isomer) }\end{array}$ & ND & ND & ND & ND & $0.36 \pm 0.0$ & ND & ND & ND & ND \\
\hline $\begin{array}{c}\text { Tetracoumaroyl spermine } \\
\text { (isomer) }\end{array}$ & ND & ND & ND & ND & $0.03 \pm 0.0$ & ND & ND & ND & ND \\
\hline $\begin{array}{l}\text { Tetracoumaroyl spermine } \\
\text { (isomer) }\end{array}$ & ND & $0.99 \pm 0.0$ & ND & ND & $0.36 \pm 0.0$ & ND & ND & ND & ND \\
\hline $\begin{array}{l}\text { Tetracoumaroyl spermine } \\
\text { (isomer) }\end{array}$ & ND & ND & ND & ND & $0.23 \pm 0.0$ & ND & ND & ND & ND \\
\hline $\begin{array}{l}\text { Total amount of phenolic } \\
\text { compounds }\end{array}$ & 0.2 & 0.1 & 2.6 & 0.1 & 0.0 & 0.4 & 0.1 & 0.0 & 0.4 \\
\hline Total amount of phenylamides & 3.7 & 2.9 & 14.7 & 0.0 & 1.2 & 0.0 & 0.0 & 0.0 & 0.0 \\
\hline
\end{tabular}

Values expressed as milligram of each compound/g sample. ND = not detected. 
Table 4. Phenolic and phenylamide compounds of the bee bread samples obtained after each in vitro digestion phase.

\begin{tabular}{|c|c|c|c|c|c|c|c|c|c|}
\hline \multirow{2}{*}{ Compound } & \multicolumn{3}{|c|}{ Mouth } & \multicolumn{3}{|c|}{ Stomach } & \multicolumn{3}{|c|}{ Intestine } \\
\hline & BB-A1 & BB-A2 & BB-A3 & BB-A1 & BB-A2 & BB-A3 & BB-A1 & BB-A2 & BB-A3 \\
\hline Methyl herbacetin-O-dihexoside & $0.41 \pm 0.0$ & $0.33 \pm 0.0$ & $0.07 \pm 0.0$ & $0.22 \pm 0.0$ & $0.16 \pm 0.0$ & $0.06 \pm 0.0$ & $0.16 \pm 0.0$ & $0.12 \pm 0.0$ & $0.04 \pm 0.0$ \\
\hline Methyl herbacetin-O-rutinoside & $0.08 \pm 0.0$ & $0.08 \pm 0.0$ & $0.01 \pm 0.0$ & $0.05 \pm 0.0$ & $0.05 \pm 0.0$ & ND & $0.04 \pm 0.0$ & $0.04 \pm 0.0$ & ND \\
\hline $\begin{array}{l}\text { Isorhamnetin-O-pentosyl } \\
\text { hexoside }\end{array}$ & $0.05 \pm 0.0$ & $0.06 \pm 0.0$ & $0.04 \pm 0.0$ & $0.02 \pm 0.0$ & ND & $0.03 \pm 0.0$ & $0.02 \pm 0.0$ & ND & $0.04 \pm 0.0$ \\
\hline Kaempferol-3-O-rutinoside & $0.01 \pm 0.0$ & $0.01 \pm 0.0$ & $0.01 \pm 0.0$ & $0.00 \pm 0.0$ & $0.00 \pm 0.0$ & $0.01 \pm 0.0$ & ND & $0.00 \pm 0.0$ & $0.00 \pm 0.0$ \\
\hline Quercetin-3-O-glucoside & ND & ND & $0.01 \pm 0.0$ & ND & ND & $0.00 \pm 0.0$ & ND & ND & ND \\
\hline Quercetin-O-malonyl hexoside & ND & $0.02 \pm 0.0$ & $0.02 \pm 0.0$ & ND & ND & ND & ND & ND & ND \\
\hline Methyl herbacetin-3-O-hexoside & $0.02 \pm 0.0$ & ND & ND & $0.01 \pm 0.0$ & ND & ND & ND & ND & ND \\
\hline Kaempferol-O-hexoside & ND & $0.00 \pm 0.0$ & $0.01 \pm 0.0$ & ND & ND & ND & ND & ND & ND \\
\hline Isorhamnetin-O-hexoside & ND & $0.01 \pm 0.0$ & ND & ND & ND & ND & ND & ND & ND \\
\hline Kaempferol-O-malonyl hexoside & ND & $0.03 \pm 0.0$ & $0.03 \pm 0.0$ & ND & $0.01 \pm 0.0$ & $0.03 \pm 0.0$ & ND & $0.01 \pm 0.0$ & $0.02 \pm 0.0$ \\
\hline $\begin{array}{c}N^{1}, N^{5} \\
N^{10} \text {-tri-caffeoylspermidine }\end{array}$ & $1.84 \pm 0.1$ & $4.14 \pm 0.2$ & $0.40 \pm 0.0$ & $0.07 \pm 0.0$ & $0.09 \pm 0.0$ & ND & ND & ND & ND \\
\hline $\begin{array}{c}N^{1} \text {-feruloyl- } N^{5}, \\
N^{10} \text {-dicaffeoylspermidine } \\
N^{1} \text {-feruloyl- } N^{5}\end{array}$ & ND & $0.06 \pm 0.0$ & ND & ND & ND & ND & ND & ND & ND \\
\hline $\begin{array}{c}N^{10} \text {-dicaffeoylspermidine } \\
\text { (isomer) }\end{array}$ & ND & $0.17 \pm 0.0$ & ND & ND & ND & ND & ND & ND & ND \\
\hline $\begin{array}{c}N^{1}-p \text {-coumaroyl- } N^{5} \\
N^{10} \text {-dicaffeoylspermidine } \\
N^{1}-p \text {-coumaroyl- } N^{5}\end{array}$ & $0.21 \pm 0.0$ & $0.13 \pm 0.0$ & $0.06 \pm 0.0$ & ND & ND & ND & ND & ND & ND \\
\hline $\begin{array}{l}N^{10} \text {-dicaffeoylspermidine } \\
\text { (isomer) }\end{array}$ & $0.50 \pm 0.0$ & $1.48 \pm 0.0$ & $0.69 \pm 0.0$ & ND & $0.03 \pm 0.0$ & ND & ND & ND & ND \\
\hline $\begin{array}{l}N^{1}, N^{5} \text {-di-p-coumaroyl- } N^{10}- \\
\text { caffeoylspermidine }\end{array}$ & $0.30 \pm 0.0$ & $0.07 \pm 0.0$ & $0.66 \pm 0.0$ & ND & ND & ND & ND & ND & ND \\
\hline $\begin{array}{c}N^{1}, N^{5}-d i-p \text {-coumaroyl- } N^{10}- \\
\text { caffeoylspermidine } \\
\text { (isomer) }\end{array}$ & $1.23 \pm 0.0$ & $1.79 \pm 0.1$ & ND & $0.07 \pm 0.0$ & ND & ND & ND & ND & ND \\
\hline $\begin{array}{c}N^{1}, N^{5} \\
N^{10} \text {-tri-p-coumaroylspermidine }\end{array}$ & $\begin{array}{c}12.25 \pm \\
0.1\end{array}$ & $\begin{array}{c}19.78 \pm \\
0.2\end{array}$ & $7.17 \pm 0.1$ & $0.42 \pm 0.0$ & $0.18 \pm 0.0$ & ND & ND & ND & ND \\
\hline Methyl herbacetin & ND & ND & $0.09 \pm 0.0$ & ND & ND & ND & ND & ND & ND \\
\hline Feruloyl dicoumaroyl spermidine & $0.54 \pm 0.1$ & $0.50 \pm 0.1$ & ND & ND & ND & ND & ND & ND & ND \\
\hline Tetracoumaroyl spermine & $0.59 \pm 0.0$ & $0.23 \pm 0.0$ & ND & ND & ND & ND & ND & ND & ND \\
\hline $\begin{array}{l}\text { Tetracoumaroyl spermine } \\
\text { (isomer) }\end{array}$ & $0.69 \pm 0.0$ & ND & ND & ND & ND & ND & ND & ND & ND \\
\hline $\begin{array}{c}\text { Tetracoumaroyl spermine } \\
\text { (isomer) }\end{array}$ & $0.68 \pm 0.1$ & ND & ND & ND & ND & ND & ND & ND & ND \\
\hline $\begin{array}{l}\text { Tetracoumaroyl spermine } \\
\text { (isomer) }\end{array}$ & $1.14 \pm 0.1$ & ND & ND & ND & ND & ND & ND & ND & ND \\
\hline $\begin{array}{l}\text { Total amount of phenolic } \\
\text { compounds }\end{array}$ & 0.6 & 0.6 & 0.3 & 0.3 & 0.2 & 0.1 & 0.2 & 0.2 & 0.1 \\
\hline Total amount of phenylamides & 19.9 & 28.4 & 8.9 & 0.5 & 0.3 & 0.0 & 0.0 & 0.0 & 0.0 \\
\hline
\end{tabular}

Values expressed as milligram of each compound/g sample. $\mathrm{ND}=$ not detected.

\subsection{Antioxidant Capacity}

Antioxidant capacities of undigested and digested bee pollen and bee bread samples were measured using DPPH free radicals scavenging activity and reducing power assays. Among raw bee pollen samples, BP-A3 showed both the highest free radical scavenging $\left(\mathrm{EC}_{50}: 0.14 \pm 0.0 \mathrm{mg} / \mathrm{mL}\right)$ and reducing power activity $(5.0 \pm 0.1 \mathrm{mg} \mathrm{GAE} / \mathrm{g})$, much better than BP-A1 and BP-A2 (Figure 5). In raw bee bread samples, the behavior did not change much between them, with BB-A2 exhibiting the highest free radical scavenging activity with a value of $0.23 \pm 0.0 \mathrm{mg} / \mathrm{mL}$ and reducing power activity with $5.6 \pm 0.3 \mathrm{mg}$ GAE $/ \mathrm{g}$, which is in accordance with previous studies that reported that bee pollen and bee bread may have different antioxidant activity $[4,40]$.

At the end of in vitro gastrointestinal digestion, a decrease of $35-85 \%$ in free radicals scavenging capacity and of $47-76 \%$ in reducing power occurred for bee pollen samples, while in bee bread samples, there was a decrease of $69-74 \%$ in free radicals scavenging capacity and of $33-50 \%$ in reducing power activity (Figure 5). In addition, all bee pollen samples showed a steadily decreasing trend in terms of DPPH scavenging activity after each digestion phase. The same situation was observed in reducing power activity, except in the intestinal phase for BP-A3. As expected, the BP-A3, which has the highest antioxidant activity in the undigested samples, also showed the highest activity at the end of digestion, for both tests. These differences in bee pollen samples may be related to the high content released from samples and slowing down in the intestinal phase or the degradation of the released compounds under conditions in the intestinal phase $[19,21]$. 

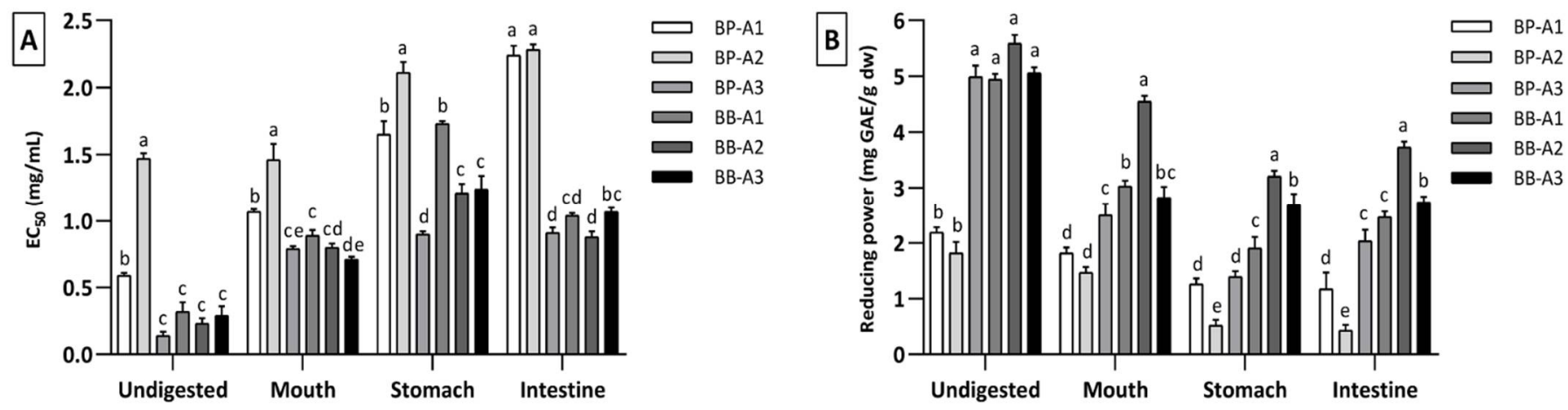

Figure 5. Antioxidant capacities of bee pollen and bee bread samples: (A) DPPH free radical scavenging and (B) reducing power activity of the undigested and digested samples after each in vitro digestion phase. Within each group (undigested, mouth, stomach and intestine), different letters (a-e) mean significantly different $(p<0.05)$.

All bee bread samples showed a higher antioxidant capacity at the end of the intestinal phase compared to the gastric phase. Several other studies, with different food matrices, report the same behavior during digestion, emphasizing that antioxidant activity was higher in the intestinal phase compared to the gastric phase [13,22]. A comparison between bee pollen and bee bread revealed that, for both antioxidant assays, bee bread showed higher antioxidant activity at the end of digestion than bee pollen.

The correlation between bioactive compounds and antioxidant capacity in bee pollen and bee bread was evaluated (Supplementary Material, Table S2). Accordingly, the DPPH value showed significant and very strong positive correlation with both TPC $(\mathrm{r}=0.799$; $p<0.01)$ and TFC $(\mathrm{r}=0.784 ; p<0.01)$. The reducing power value was positively correlated strongly with TPC $(\mathrm{r}=0.743 ; p<0.01)$, while it was moderately correlated with TFC $(\mathrm{r}=0.562 ; p<0.01)$. The moderate correlation of reducing power with TFC compared to TPC could be attributed to the effect of digestion on the structure of flavonoids, and this is clearly seen in Figure 2. Besides, these results are supported by the findings given above, where samples with high TPC and TFC generally exhibited higher antioxidant activity. Correlation analysis indicates that the antioxidant compounds in bee pollen and bee bread are not only potent radical scavengers but also good reducing agents.

\section{Conclusions}

Bee pollen and bee bread were analyzed for botanical origin, bioactive compounds, and antioxidant capacity using an in vitro simulated gastrointestinal digestion model. The palynological analysis revealed that Plantaginaceae, Asteraceae, Fabaceae and Fagaceae were the dominant plant families. The in vitro digestion results showed that the bioactive compounds in bee pollen and bee bread generally tended to decrease throughout digestion with some exceptions. Besides, the decrease or increase in phenolic compounds in both bee products affected their antioxidant activities. Especially, the gastric phase was found to be an important factor on the bioavailability of bioactive compounds. Moreover, bee bread was more digestible than bee pollen. Considering all these findings, both bee products have an important potential for the food industry. Besides the use in the food industry, bee pollen and bee bread can find a number of applications in different fields, thanks to their phenolic compound content.

Supplementary Materials: The following are available online at www.mdpi.com/xxx/s1: Table S1: Preparation of stock solutions of simulated digestion fluids: simulated saliva fluid (SSF), gastric fluid (SGF) and intestinal fluid (SIF) stock solutions; Table S2: Correlation analysis between phenolic content and antioxidant capacity.

Author Contributions: V.A.; Conceptualization; Methodology; Investigation; Writing-Original Draft; Writing—Review and Editing; Visualization, A.T.; Methodology, P.R.-A.; Methodology, Investigation S.I.F.; Conceptualization; Methodology; Formal analysis; Writing—Original Draft; Writing- 
Review and Editing; Validation, M.V.-B.; Conceptualization; Writing-Original Draft; WritingReview and Editing; Resources; Supervision; Project administration. All authors have read and agreed to the published version of the manuscript.

Funding: The authors are grateful to the Foundation for Science and Technology (FCT, Portugal) for financial support by national funds FCT/MCTES to CIMO (UIDB/00690/2020). Thanks to the Programa Apícola Nacional 2020-2022 (National Beekeeping Program) for funding the project "Standardization of production procedures and quality parameters of bee products" and to Project PDR2020-1.0.1-FEADER-031734: "DivInA-Diversification and Innovation on Beekeeping Production". National funding by FCT- Foundation for Science and Technology, through the institutional scientific employment program-contract with Soraia I. Falcão.

Institutional Review Board Statement: Not applicable.

Informed Consent Statement: Not applicable.

Data Availability Statement: Not applicable.

Conflicts of Interest: The authors declare no conflict of interest. The funders had no role in the design of the study; in the collection, analyses, or interpretation of data; in the writing of the manuscript, or in the decision to publish the results.

\section{References}

1. Kieliszek, M.; Piwowarek, K.; Kot, A.M.; Błażejak, S.; Chlebowska-Śmigiel, A.; Wolska, I. Pollen and bee bread as new healthoriented products: A review. Trends Food Sci. Technol. 2018, 71, 170-180. [CrossRef]

2. Campos, M.G.; Bogdanov, S.; de Almeida-Muradian, L.B.; Szczesna, T.; Mancebo, Y.; Frigerio, C.; Ferreira, F. Pollen composition and standardisation of analytical methods. J. Apic. Res. 2008, 47, 154-161. [CrossRef]

3. Feás, X.; Vázquez-Tato, M.P.; Estevinho, L.; Seijas, J.A.; Iglesias, A. Organic bee pollen: Botanical origin, nutritional value, bioactive compounds, antioxidant activity and microbiological quality. Molecules 2012, 17, 8359-8377. [CrossRef] [PubMed]

4. Tomás, A.; Falcão, S.I.; Russo-Almeida, P.; Vilas-Boas, M. Potentialities of beebread as a food supplement and source of nutraceuticals: Botanical origin, nutritional composition and antioxidant activity. J. Apic. Res. 2017, 56, 219-230. [CrossRef]

5. Bakour, M.; Fernandes, Â.; Barros, L.; Sokovic, M.; Ferreira, I.C. Bee bread as a functional product: Chemical composition and bioactive properties. LWT 2019, 109, 276-282. [CrossRef]

6. Negri, G.; Barreto, L.M.R.C.; Sper, F.L.; Carvalho, C.D.; Campos, M.D.G.R. Phytochemical analysis and botanical origin of Apis mellifera bee pollen from the municipality of Canavieiras, Bahia State, Brazil. Braz. J. Food Technol. 2018, 21, e2016176. [CrossRef]

7. Estevinho, L.M.; Rodrigues, S.; Pereira, A.P.; Feás, X. Portuguese bee pollen: Palynological study, nutritional and microbiological evaluation. Int. J. Food Sci. Technol. 2012, 47, 429-435. [CrossRef]

8. Kaškonienè, V.; Adaškevičiūtè, V.; Kaškonas, P.; Mickienè, R.; Maruška, A. Antimicrobial and antioxidant activities of natural and fermented bee pollen. Food Biosci. 2020, 34, 100532. [CrossRef]

9. El Ghouizi, A.; El Menyiy, N.; Falcão, S.I.; Vilas-Boas, M.; Lyoussi, B. Chemical composition, antioxidant activity, and diuretic effect of Moroccan fresh bee pollen in rats. Vet. World 2020, 13, 1251-1261. [CrossRef]

10. Sobral, F.; Calhelha, R.C.; Barros, L.; Dueñas, M.; Tomás, A.; Santos-Buelga, C.; Vilas-Boas, M.; Ferreira, I.C. Flavonoid composition and antitumor activity of bee bread collected in northeast Portugal. Molecules 2017, 22, 248. [CrossRef]

11. Bartkiene, E.; Lele, V.; Sakiene, V.; Zavistanaviciute, P.; Zokaityte, E.; Dauksiene, A.; Jagminas, P.; Klupsaite, D.; Bliznikas, S.; Ruzauskas, M. Variations of the antimicrobial, antioxidant, sensory attributes and biogenic amines content in Lithuania-derived bee products. LWT 2020, 118, 108793. [CrossRef]

12. Mărgăoan, R.; Stranț, M.; Varadi, A.; Topal, E.; Yücel, B.; Cornea-Cipcigan, M.; Campos, M.G.; Vodnar, D.C. Bee collected pollen and bee bread: Bioactive constituents and health benefits. Antioxidants 2019, 8, 568. [CrossRef]

13. Yesiltas, B.; Capanoglu, E.; Firatligil-Durmus, E.; Sunay, A.E.; Samanci, T.; Boyacioglu, D. Investigating the in-vitro bioaccessibility of propolis and pollen using a simulated gastrointestinal digestion System. J. Apic. Res. 2014, 53, 101-108. [CrossRef]

14. Benavides-Guevara, R.M.; Quicazan, M.C.; Ramírez-Toro, C. Digestibility and availability of nutrients in bee pollen applying different pretreatments. Ing. Compet. 2017, 19, 119-128.

15. Louveaux, J.; Maurizio, A.; Vorwohl, G. Methods of Melissopalynology. Bee World 1978, 59, 139-157. [CrossRef]

16. Vergeron, P. Interprétation statistique des résultats en matière d'analyse pollinique des miels. Ann. l'Abeille 1964, 7, 349-364. [CrossRef]

17. Falcão, S.I.; Freire, C.; Vilas-Boas, M. A proposal for physicochemical standards and antioxidant activity of Portuguese propolis. J. Am. Oil Chem. Soc. 2013, 90, 1729-1741. [CrossRef]

18. Minekus, M.; Alminger, M.; Alvito, P.; Ballance, S.; Bohn, T.; Bourlieu, C.; Carriere, F.; Boutrou, R.; Corredig, M.; Dupont, D. A standardised static in vitro digestion method suitable for food-an international consensus. Food Funct. 2014, 5, 1113-1124. [CrossRef] 
19. Schulz, M.; Biluca, F.C.; Gonzaga, L.V.; Borges, G.D.S.C.; Vitali, L.; Micke, G.A.; de Gois, J.S.; de Almeida, T.S.; Borges, D.L.G.; Miller, P.R.M. Bioaccessibility of bioactive compounds and antioxidant potential of juçara fruits (Euterpe edulis Martius) subjected to in vitro gastrointestinal digestion. Food Chem. 2017, 228, 447-454. [CrossRef]

20. Bouayed, J.; Hoffmann, L.; Bohn, T. Total phenolics, flavonoids, anthocyanins and antioxidant activity following simulated gastro-intestinal digestion and dialysis of apple varieties: Bioaccessibility and potential uptake. Food Chem. 2011, 128, 14-21. [CrossRef]

21. Ng, Z.X.; See, A.N. Effect of in vitro digestion on the total polyphenol and flavonoid, antioxidant activity and carbohydrate hydrolyzing enzymes inhibitory potential of selected functional plant-based foods. J. Food Process. Preserv. 2019, 43 , e13903. [CrossRef]

22. Kamiloglu, S.; Pasli, A.A.; Ozcelik, B.; van Camp, J.; Capanoglu, E. Influence of different processing and storage conditions on in vitro bioaccessibility of polyphenols in black carrot jams and marmalades. Food Chem. 2015, 186, 74-82. [CrossRef]

23. Quan, W.; Qie, X.; Chen, Y.; Zeng, M.; Qin, F.; Chen, J.; He, Z. Effect of milk addition and processing on the antioxidant capacity and phenolic bioaccessibility of coffee by using an in vitro gastrointestinal digestion model. Food Chem. 2020, 308, 125598. [CrossRef] [PubMed]

24. Pinto, J.; Spínola, V.; Llorent-Martínez, E.J.; Fernández-de Córdova, M.L.; Molina-García, L.; Castilho, P.C. Polyphenolic profile and antioxidant activities of Madeiran elderberry (Sambucus lanceolata) as affected by simulated in vitro digestion. Food Res. Int. 2017, 100, 404-410. [CrossRef]

25. Ng, Z.X.; Rosman, N.F. In vitro digestion and domestic cooking improved the total antioxidant activity and carbohydrate-digestive enzymes inhibitory potential of selected edible mushrooms. J. Food Sci. Technol. 2019, 56, 865-877. [CrossRef]

26. Ortega, N.; Macià, A.; Romero, M.-P.; Reguant, J.; Motilva, M.-J. Matrix composition effect on the digestibility of carob flour phenols by an in-vitro digestion model. Food Chem. 2011, 124, 65-71. [CrossRef]

27. Falcão, S.I.; Vale, N.; Gomes, P.; Domingues, M.R.; Freire, C.; Cardoso, S.M.; Vilas-Boas, M. Phenolic profiling of Portuguese propolis by LC-MS spectrometry: Uncommon propolis rich in flavonoid glycosides. Phytochem. Anal. 2013, 24, 309-318. [CrossRef] [PubMed]

28. Su, J.; Yang, X.; Lu, Q.; Liu, R. Antioxidant and anti-tyrosinase activities of bee pollen and identification of active components. J. Apic. Res. 2020, 1-11. [CrossRef]

29. Mihajlovic, L.; Radosavljevic, J.; Burazer, L.; Smiljanic, K.; Velickovic, T.C. Composition of polyphenol and polyamide compounds in common ragweed (Ambrosia artemisiifolia L.) pollen and sub-pollen particles. Phytochemistry 2015, 109, 125-132. [CrossRef] [PubMed]

30. Sobolev, V.S.; Sy, A.A.; Gloer, J.B. Spermidine and flavonoid conjugates from peanut (Arachis hypogaea) flowers. J. Agric. Food Chem. 2008, 56, 2960-2969. [CrossRef] [PubMed]

31. Cuyckens, F.; Claeys, M. Mass spectrometry in the structural analysis of flavonoids. J. Mass Spectrom. 2004, 39, 1-15. [CrossRef] [PubMed]

32. Barros, L.; Dueñas, M.; Carvalho, A.M.; Ferreira, I.C.; Santos-Buelga, C. Characterization of phenolic compounds in flowers of wild medicinal plants from Northeastern Portugal. Food Chem. Toxicol. 2012, 50, 1576-1582. [CrossRef] [PubMed]

33. Paupière, M.J.; Müller, F.; Li, H.; Rieu, I.; Tikunov, Y.M.; Visser, R.G.; Bovy, A.G. Untargeted metabolomic analysis of tomato pollen development and heat stress response. Plant Reprod. 2017, 30, 81-94. [CrossRef] [PubMed]

34. Anjos, O.; Fernandes, R.; Cardoso, S.M.; Delgado, T.; Farinha, N.; Paula, V.; Estevinho, L.M.; Carpes, S.T. Bee pollen as a natural antioxidant source to prevent lipid oxidation in black pudding. LWT 2019, 111, 869-875. [CrossRef]

35. Urcan, A.C.; Criste, A.D.; Dezmirean, D.S.; Mărgăoan, R.; Caeiro, A.; Graça Campos, M. Similarity of data from bee bread with the same taxa collected in India and Romania. Molecules 2018, 23, 2491. [CrossRef]

36. Edreva, A.; Velikova, V.; Tsonev, T. Phenylamides in plants. Russ. J. Plant Physiol. 2007, 54, 287-301. [CrossRef]

37. Eliašová, A.; Poracká, V.; Pal'ove-Balang, P.; Imrich, J.; Repčák, M. Accumulation of tetracoumaroyl spermine in Matricaria chamomilla during floral development and nitrogen deficiency. Z. Nat. C. J. Biosci. 2012, 67, 58-64. [CrossRef]

38. Lucas-Gonzalez, R.; Navarro-Coves, S.; Pérez-Álvarez, J.A.; Fernández-López, J.; Muñoz, L.A.; Viuda-Martos, M. Assessment of polyphenolic profile stability and changes in the antioxidant potential of maqui berry (Aristotelia chilensis (Molina) Stuntz) during in vitro gastrointestinal digestion. Ind. Crops Prod. 2016, 94, 774-782. [CrossRef]

39. Toro-Funes, N.; Bosch-Fusté, J.; Veciana-Nogués, M.T.; Izquierdo-Pulido, M.; Vidal-Carou, M.C. In vitro antioxidant activity of dietary polyamines. Food Res. Int. 2013, 51, 141-147. [CrossRef]

40. De-Melo, A.A.M.; Estevinho, L.M.; Moreira, M.M.; Delerue-Matos, C.; de Freitas, A.D.S.; Barth, O.M.; de Almeida-Muradian, L.B. A multivariate approach based on physicochemical parameters and biological potential for the botanical and geographical discrimination of Brazilian bee pollen. Food Biosci. 2018, 25, 91-110. [CrossRef] 